\title{
Climate Change Impacts on Net Ecosystem Productivity in a Subtropical Shrubland of Northwestern México
}

\author{
Vivian S. Verduzco ${ }^{1,2}$, Enrique R. Vivoni ${ }^{2,3^{*}}$, Enrico A. Yépez ${ }^{1}$, \\ Julio C. Rodríguez ${ }^{4}$, Christopher J. Watts ${ }^{5}$, Tonantzin Tarin ${ }^{1,6}$, Jaime Garatuza-Payán ${ }^{1}$, \\ Agustin Robles-Morua ${ }^{1}$ and Valeriy Y. Ivanov ${ }^{7}$
}

\footnotetext{
${ }^{1}$ Departamento de Ciencias del Agua y Medio Ambiente. Instituto Tecnológico de Sonora. Ciudad Obregón, Sonora, México, 85000

${ }^{2}$ School of Earth and Space Exploration. Arizona State University. Tempe, Arizona, USA, 85287

${ }^{3}$ School of Sustainable Engineering and the Built Environment. Arizona State University. Tempe, Arizona, USA, 85287

${ }^{4}$ Departamento de Agricultura y Ganadería. Universidad de Sonora. Hermosillo, Sonora, México, 83000

${ }^{5}$ Departamento de Física. Universidad de Sonora. Hermosillo, Sonora, México, 83000

${ }^{6}$ School of Life Sciences. University of Technology Sydney. Sydney, Australia, 2007

${ }^{7}$ Department of Civil and Environmental Engineering. University of Michigan. Ann Arbor, Michigan, USA, 48109
}

*Corresponding author: Dr. Enrique R. Vivoni, e-mail: vivoni@asu.edu

- Model simulation accurately captured the seasonality of vegetation activity.

- Net ecosystem productivity decreased under reduced summer rainfall and increased temperature scenarios.

- Elevated $\mathrm{CO}_{2}$ scenarios offset the negative impacts of meteorological conditions.

Paper 2017JG004361 Revised for

Journal of Geophysical Research-Biogeosciences
This is the author manuscript accepted forpublicatign 20 nd has undergone full peer review but has not been through the copyediting, typesetting, pagination and proofreading process, which may lead to differences between this version and the Version of Record. Please cite this article as doi: $10.1002 / 2017 J G 004361$

This article is protected by copyright. All rights reserved. 


\section{Abstract}

2

3

4 ecosystem productivity (NEP) under rising air temperature and $\mathrm{CO}_{2}$ and altered precipitation

5 regimes also hinder climate change assessments. A promising avenue for addressing this

6 challenge is through the application of numerical models. In this work, we combine a

7 mechanistic ecohydrological model and a soil carbon model to simulate soil and plant processes

8 in a subtropical shrubland of northwest México. Due to the influence of the North American

9 monsoon, the site exhibits net carbon losses early in the summer and net carbon gains during the

10 photosynthetically-active season. After building confidence in the simulations through

11 comparisons with eddy covariance flux data, we conduct a series of climate change experiments

12 for near-future (2030-2045) scenarios that test the impact of meteorological changes and $\mathrm{CO}_{2}$

13 fertilization relative to historical conditions (1990-2005). Results indicate that reductions in NEP

14 arising from warmer conditions are effectively offset by gains in NEP due to the impact of higher

$15 \mathrm{CO}_{2}$ on water use efficiency. For cases with higher summer rainfall and $\mathrm{CO}_{2}$ fertilization, climate

16 change impacts lead to an increase of $\sim 25 \%$ in NEP relative to historical conditions (mean of 66

$17 \mathrm{gC} \mathrm{m}^{-2}$ ). Net primary production and soil respiration derived from decomposition are shown to

18 be important processes that interact to control NEP and, given the role of semiarid ecosystems in

19 the global carbon budget, deserve attention in future simulation efforts of ecosystem fluxes.

20 Keywords: ecohydrology; eddy covariance; carbon fluxes; modeling; climate change; North

21 American monsoon. 


\section{Introduction}

Although the carbon sink strength of semiarid ecosystems is still under debate (Xiao et

24 al., 2011), recent studies have recognized that these areas have a dominant role, stronger than

25 other biogeographic regions, in regulating the intra- and inter-annual variability of the global

26 carbon cycle (Ahlström et al., 2015; Poulter et al., 2014). A transition to more arid conditions

27 (e.g. increasing temperatures and prolonged drought spells) in these regions (Pachauri et al.,

28 2014; Seager et al., 2007) will have implications on the productivity of semiarid ecosystems.

29 This is the case for most of the North American monsoon (NAM) region, which comprises

30 semiarid areas in the southwestern United States and northwestern México (Douglas et al., 1993;

31 Vivoni et al., 2008). The NAM system is a pronounced increase in precipitation during the warm

32 season (July-September) leading to increased biological activity (Flato et al., 2013; Forzieri et

33 al., 2014). Remote sensing analyses have quantified the spatial and temporal variability of

34 vegetation greening during the NAM (e.g. Tang et al., 2012; Watts et al., 2007). However,

35 ecosystem processes regulating the carbon cycling are not understood well enough to anticipate

36 the implications of climate change on the net carbon balance of these semiarid ecosystems.

The eddy covariance (EC) technique has become a useful approach for measuring water, energy and carbon fluxes at the ecosystem level (Baldocchi et al., 2001), with several studies conducted in different ecosystems in the NAM region (e.g. Anderson \& Vivoni, 2016; Méndez-

40 Barroso et al., 2014; Pérez-Ruiz et al., 2010; Scott et al., 2010, 2015; Yépez et al., 2007). By

41 quantifying carbon dioxide $\left(\mathrm{CO}_{2}\right)$ exchanges between ecosystems and the overlying atmosphere

42 (Loescher et al., 2003), net ecosystem productivity (NEP) can be measured via the EC method as

43 a degree of the metabolic activity of a terrestrial ecosystem. Furthermore, traditional flux

44 partitioning models have been applied to estimate NEP components, gross primary productivity 
45 (GPP) and ecosystem respiration $\left(\mathrm{R}_{\mathrm{ECO}}\right)$ (Reichtein et al., 2005, Stoy et al., 2006). Since NEP

46 consists of the difference between GPP and $\mathrm{R}_{\mathrm{ECO}}$, its response to hydrometeorological conditions

47 has been difficult to identify (Nayak et al., 2015; Scott et al., 2015; Biederman et al., 2016). This

48 is primarily due to the differential sensitivity of GPP and $\mathrm{R}_{\mathrm{ECO}}$ to changes in temperature and

49 precipitation (e.g. Euskirchen et al., 2014; Shi et al., 2014). As a result, semiarid ecosystem

50 responses to climate change remain highly uncertain. On the one hand, GPP may be reduced by

51 warming via plant heat stress (Sage \& Kubien, 2007) and via stomatal closure from increased

52 evaporative demand and reductions of soil water content (Seneviratne et al., 2010; Williams et

53 al., 2013) affecting vegetation productivity (Novick et al., 2016). For instance, Biederman et al.

54 (2017) found that warm temperatures have a negative effect on NEP in semiarid ecosystems of

55 southwestern North America. Stomata respond to transpiration rates in a process known as the

56 apparent 'feed-forward response', implying that transpiration strongly decreases at high vapor

57 pressure deficit, particularly during periods of water stress (Duurmsa et al., 2014; Novick et al.,

58 2016). When stomata close in this manner, carbon assimilation and GPP decrease, thus reducing

59 NEP. Photosynthetic enhancements due to rising $\mathrm{CO}_{2}$ atmospheric concentrations (Smith et al.,

60 2000) and the lengthening of the growing season (Kunkel, 2016), however, may increase GPP.

61 These changes are known to affect ecosystem water use efficiency (WUE = GPP /

62 evapotranspiration (ET)), a measure of the sensitivity of photosynthesis rates to changes in

63 hydroclimatic conditions (Yang et al., 2016). In addition, changes in rainfall timing, intensity and

64 distribution are also important factors affecting NEP, though the net effect or directionality are

65 unclear (Allard et al., 2008; Gherardi \& Sala, 2015; Heisler-White et al., 2008; Miranda et al.,

66 2011; Robertson et al., 2009; Rohr et al., 2013; Ross et al., 2012; Xie et al., 2015). 
Similarly, the effects of climate change on $\mathrm{R}_{\mathrm{ECO}}$ in semiarid ecosystems are uncertain due to complex dynamics occurring during periods of water availability (Collins et al., 2014; Fan et al., 2012). $\mathrm{R}_{\mathrm{ECO}}$ integrates plant (autotrophic) and microbial (heterotrophic) processes that are coupled (Sacks et al., 2007; Verduzco et al., 2015) and has been shown to either increase,

71 decrease or remain unchanged under warming conditions (Arnone et al., 2008; Lenton \& 72 Huntingford, 2003; Luo et al., 2001; Zhou et al., 2007). $\mathrm{R}_{\mathrm{ECO}}$ is also highly variable under different precipitation conditions (Cable et al., 2008; Harper et al., 2005; Thomey et al., 2011). Some studies have found that warming can substantially increase cellular metabolic maintenance 75 (e.g. Amthor, 1984; Ryan, 1991), which in turn affects autotrophic respiration $\left(\mathrm{R}_{\mathrm{a}}\right)$. Although studies have shown that plants can acclimate to increasing temperatures (Slot and Kitajima, 2015), it is still unknown the degree of and time to acclimation for different plant functional

types (Drake et al., 2015; Yamori et al., 2014). Furthermore, heterotrophic respiration has been observed to respond positively to temperature (Lloyd \& Taylor, 1994), but its sensitivity has been related to limiting factors such as substrate availability and quality, which are coupled to primary productivity (Sponseller, 2007; Zhou et al., 2013) and soil water content (Conant et al., 2004; Davidson et al., 2006; Liu et al., 2009).

Given the uncertainties in quantifying the net carbon response of semiarid ecosystems to climate change, a useful approach for addressing this problem is by combining ecosystem level measurements and numerical modeling. Previous efforts have found misrepresentation in the modeling of semiarid ecosystem carbon fluxes (e.g. Huntzinger et al., 2012; Vargas et al., 2013), net carbon balance (Keenan et al., 2012), and its responses to climate change (Friedlingstein et al., 2013). While simulating water, energy and carbon fluxes remains challenging in semiarid ecosystems (Fisher et al., 2014; Li et al., 2004; Xu et al., 2013), there has been much progress on 
coupled water-vegetation model representations in recent years (Fatichi et al., 2016b). Included

91 in these advances are more accurate representations of ecosystem processes at shorter temporal

92 scales and the simulation of longer-term phenological variations for different plant functional

93 types (e.g. Ivanov et al., 2008a, 2008b). In addition, finer representations of event-scale and

94 seasonal precipitation effects on vegetation dynamics have been achieved, leading to plant

95 carbon assimilation into a number of pools that are essential for capturing vegetation dynamics

96 (e.g. Fatichi et al., 2016b; Ivanov et al., 2008a, 2008b). Given the importance of heterotrophic

97 respiration in semiarid ecosystems (Cable et al., 2008; Verduzco et al., 2015; Yépez et al., 2007),

98 an appropriate representation of this process is necessary for simulating the annual cycle and

99 interannual variability of NEP as well as identifying the impacts of different climate change

100 drivers (e.g. rising $\mathrm{CO}_{2}$ and changing meteorological conditions).

In this contribution, we combine the mechanistic ecohydrological model of Ivanov et al.

102 (2008a) (TIN-based Real-time Integrated Basin Simulator - Vegetation Generation Interactive

103 Evolution, tRIBS-VEGGIE, model) with the soil carbon model (SCM) of Porporato et al. (2003)

104 to describe ecosystem plant and soil processes (e.g. gross primary productivity, autotrophic and

105 heterotrophic respiration) controlling NEP in a subtropical shrubland in northwestern México. In

106 contrast to prior efforts (e.g. terrestrial biosphere models, Huntzinger et al., 2012), the combined

107 tRIBS-VEGGIE and SCM approach tracks energy, water, temperature and substrate limitations

108 on photosynthesis and respiration from multiple carbon pools using process-level prognostic

109 equations that are tailored to seasonally-dry ecosystems. We use a five-year long record of EC

110 flux and meteorological data (Méndez-Barroso et al., 2014; Villarreal et al., 2016) from a

111 subtropical shrubland as well as remote sensing products to calibrate and test the model

112 simulations for its ability to realistically capture water fluxes, vegetation dynamics and the 
113 components of net ecosystem productivity (NEP = GPP - $\left.\mathrm{R}_{\mathrm{ECO}}\right)$. After model confirmation, we

114 conduct a series of climate change experiments using long-term forcing generated by the

115 stochastic downscaling of a set of climate projections from Taylor et al. (2012) that represent

116 near-future (2030-2045) meteorological and atmospheric $\mathrm{CO}_{2}$ conditions as well as a historical

117 forcing dataset of equivalent length (1990-2005). We selected the near-future period to avoid the

118 potential for dramatic changes in ecosystem composition due to climate change impacts.

119 Combining tRIBS-VEGGIE and SCM within the climate change experiments allowed us to pose

120 the following questions: (1) What are the mechanisms through which soil-plant processses

121 control NEP in seasonally-dry, semiarid ecosystems?, (2) What, if any, will be the impacts of

122 climate change on NEP and its components in the subtropical shrubland?, and (3) What is the net

123 effect of projected changes in meteorological conditions and atmospheric $\mathrm{CO}_{2}$ on $\mathrm{NEP}$ ? As a

124 result, this study aims to understand the potential effects of climate change on ecosystem

125 dynamics and carbon cycling in semiarid areas experiencing strong seasonality.

126

This article is protected by copyright. All rights reserved. 


\section{2. Materials and methods}

\section{$128 \quad$ 2.1. Site description}

The study site is a subtropical shrubland located $\sim 120 \mathrm{~km}$ northeast of Hermosillo,

130 Sonora, México $\left(29.74{ }^{\circ} \mathrm{N}, 110.53^{\circ} \mathrm{W}\right)$ near the rural town of Rayón at an elevation of $632 \mathrm{~m}$.

131 The local climate is semiarid (Köppen classification BSh) with hot summers and cool winters.

132 The long-term (1961-2009) average annual temperature and precipitation ( \pm 1 standard deviation) are $21.4 \pm 6.4{ }^{\circ} \mathrm{C}$ and $487 \pm 181 \mathrm{~mm} \mathrm{yr}^{-1}$, as obtained from Comisión Nacional del Agua station 00026181 at Rayón, Sonora. Conditions during the study period (2008-2012) were similar to the long-term average, with a mean annual air temperature (TA) of $22.7 \pm 0.6{ }^{\circ} \mathrm{C}$ and precipitation (P) of $481 \pm 92.8 \mathrm{~mm} \mathrm{yr}^{-1}$. Precipitation during the NAM season (July-September) is approximately $76 \%$ of the annual total at the site (Vivoni et al., 2010a) leading to a peak in vegetation greenness in the month of August (Méndez-Barroso et al., 2009). Site vegetation is composed of drought-deciduous trees and shrubs, including torote papelío (Jatropha cordata), tree ocotillo (Fouquieria macdougalii), acacia (Acacia cochliacantha), palo verde (Parkinsonia

praecox), Mexican mimosa (Mimosa distachya) and velvet mesquite (Prosopis velutina) as well as organpipe cactus (Stenocereus thurberi). Brown (1994) described the vegetation characteristics of subtropical shrublands (or Sinaloan thornscrub) in greater detail. The site topography is relatively flat in proximity to the EC tower (Vivoni et al., 2010b), while the soils are shallow ( 1 m) and classified as regosol-yermosol (INEGI, 2010) with sandy loam (0 to 30 $\mathrm{cm})$ and sandy clay (30 to $100 \mathrm{~cm}$ ) texture. Prior studies further describe the site properties used here for the model application, including the soil hydraulic properties, the vegetation albedo, and structural properties (e.g. Méndez-Barroso et al., 2014; Vivoni et al., 2010a, 2010b). 


\subsection{Site measurements}

Meteorological flux measurements were performed using the EC technique (Baldocchi, 2003, 2008) using a three-dimensional sonic anemometer (CSAT-3, Campbell Sci.) and an openpath infrared gas analyzer (LI-7500, Li-COR Inc.) placed on a $9 \mathrm{~m}$ tower over the tree canopy of around $6 \mathrm{~m}$ height and oriented with the prevailing southwest wind direction. Vivoni et al. (2010b) describes the EC installation at the site, including the characteristics of the footprint (20 Hz), collected with a CR5000 datalogger (Campbell Sci.) and processed to 30 min averaged quantities to obtain latent (LE) and sensible heat flux $(\mathrm{H})$ and net ecosystem exchange (NEE) of $\mathrm{CO}_{2}$, as described in the following section. By convention, negative NEE values indicate ecosystem carbon uptake from the atmosphere, which correspond to a positive net ecosystem productivity (i.e. $-\mathrm{NEE}=\mathrm{NEP})$. Net radiation $\left(\mathrm{R}_{\text {net }}\right)$ was measured using a CNR Lite2 (Kipp and Zonen) radiometer, and incoming solar radiation with a CMP3 radiometer (Campbell Sci.). For use in the model, incoming solar radiation was partitioned into direct and diffuse components of the visible (VIS, 0.4-0.7 $\mu \mathrm{m}$ ) and near infrared (NIR, 0.7-1.3 $\mu \mathrm{m}$ ) bands following the procedures of Spitters (1986), while incoming longwave radiation was estimated as a function of air temperature (Duarte et al., 2006). A humidity and air temperature sensor (HMP45D, Vaisala) was used to obtain vapor pressure (VP) and air temperature. Volumetric soil water content (SWC) was obtained as the average of two reflectometer (CS616-L, Campbell Sci.) measurements at a $10 \mathrm{~cm}$ depth over the period 2008-2010 and from a soil moisture sensor (ECH2O probe, Decagon Devices) at the same depth and location for portions of 2012. No additional soil moisture sensors at larger soil depths were available. Local precipitation was measured with a tipping-bucket rain gauge (TB4, Hydrological Services). All meteorological 
measurements were recorded as 30 min averages within the CR5000 datalogger and averaged to hourly inputs for the model applications. Additional information on measurements is presented by Méndez-Barroso et al. (2014), Villarreal et al. (2016) and Vivoni et al. (2010a).

Several data gaps occurred during the 2008-2012 period (i.e. 15 to $26 \%$ of measurements during all years, except 2008 with 63\% missing data since observations started in the summer). We followed the procedure of Robles-Morua et al. (2012) to fill in the necessary meteorological forcing. This process consisted of bias-correcting the surface meteorological data obtained from the North American Land Data Assimilation System (NLDAS) (Mitchell et al., 2004) in the grid pixel $(12 \mathrm{~km})$ corresponding to the study site during periods of simultaneous ground data. Linear corrections were applied to hourly variables of atmospheric pressure, incoming solar radiation and vapor pressure, while air temperature was corrected using the adiabatic lapse rate $\left(6.5^{\circ} \mathrm{C}\right.$ $\mathrm{km}^{-1}$ ) to match the site elevation. A logarithmic profile adjustment was used to modify the $10 \mathrm{~m}$ NLDAS wind speed to $2 \mathrm{~m}$ height assumed for all forcing variables in the ecohydrological model (tRIBS-VEGGIE). The use of bias-corrected NLDAS products to gap-fill the ground-based data was deemed important to create a continuous series of meteorological forcing.

In addition, we utilized remotely-sensed data from the Moderate Resolution Imaging Spectroradiometer (MODIS; ORNL DAAC, 2008) to test the model representation of vegetation dynamics, following Méndez-Barroso et al. (2014). Cloud-free composites of the Normalized Difference Vegetation Index (NDVI, 16 day, 250 m, MOD13Q1) and Leaf Area Index (LAI, 8 day, $1 \mathrm{~km}$, MOD15A2) were linearly interpolated to a daily product for this purpose. Due to its higher temporal resolution, we report the model evaluation against LAI for assessing vegetation dynamics. Previous research in semiarid areas has been shown to find good agreement between ground-based vegetation conditions and MODIS (i.e. Fensholt et al., 2004; Jenerette et al., 2010), 
197 but it should be noted that there are discrepancies between the site conditions and inferred

198 variables of the remote sensing products due to different spatio-temporal resolutions and

199 sometimes due to scattering and absorption by the atmospheric composition (Nagol et al., 2009).

\subsection{Flux quality control and partitioning}

Conventional corrections were applied to EC measurements following Scott et al. (2004), including removal of outliers (gas concentrations greater than \pm 4 standard deviations, Massman, 2001), a correction for density fluctuations (Webb et al., 1980) and the application of the double rotation method (Wilczak et al., 2001). In addition, friction velocity (u*) was calculated according to quantitative methods (Scott et al., 2004) and periods of time with a friction velocity less than $\mathrm{u}^{*}=0.20 \mathrm{~m} \mathrm{~s}^{-1}$ were filtered (Aubinet et al., 2000; Xu \& Baldocchi, 2004) to reduce nighttime flux underestimation (Barr et al., 2013). The $\mathrm{u}^{*}$ threshold was selected such that there is no dependence between nighttime fluxes and friction velocity. Resulting data gaps were filled in following the procedures of the Eddy Covariance Gap-Filling and Flux-Partitioning Tool available at: http://www.bgc-jena.mpg.de/ MDIwork/eddyproc/index.php, following Reichstein

212 et al. (2005). The surface energy balance was evaluated at the study site by Villarreal et al.

213 (2016) over 2008-2010 (a closure of 0.89) and Méndez-Barroso et al. (2014) over summers in 214 2006-2009 (a closure of 0.75). The partitioning of NEE into its components GPP and $\mathrm{R}_{\mathrm{ECO}}$ (i.e.

$215 \mathrm{NEE}=\mathrm{R}_{\mathrm{ECO}}-\mathrm{GPP}$ ) was carried out using the sensitivity of $\mathrm{R}_{\mathrm{ECO}}$ to air temperature (Flanagan et al., 2002; Reichstein et al., 2005). This NEE partitioning approach has been shown to be

217 consistent with other methods (Babst et al., 2014; Desai et al., 2008). 


\subsection{Ecohydrological and soil carbon modeling}

Water, energy and carbon dynamics at the subtropical shrubland were simulated using a combination of an ecohydrological model (tRIBS-VEGGIE, Ivanov et al., 2008a, 2008b) and a soil carbon model (SCM, Porporato et al., 2003) coupled through the production of litter and the soil moisture and temperature conditions (Fig. 1). Following prior efforts in semiarid regions (Bisht, 2010; Sivandran \& Bras, 2012), a drought-deciduous C3 shrub was used as the plant functional type in the one-dimensional simulations using an irregular subsurface mesh (25 layers over $1 \mathrm{~m} \mathrm{depth).} \mathrm{In} \mathrm{addition} \mathrm{to} \mathrm{vertically-resolved} \mathrm{soil} \mathrm{hydrologic} \mathrm{and} \mathrm{thermal} \mathrm{dynamics,} \mathrm{tRIBS-}$ VEGGIE captures a set of biophysical and biochemical plant processes, such as photosynthesis, autotrophic respiration $\left(\mathrm{R}_{\mathrm{a}}\right)$, carbon allocation to foliage, sapwood and fine roots, tissue turnover and vegetation phenology. This allows the estimation of gross and net (NPP $=$ GPP $-\mathrm{R}_{\mathrm{a}}$ ) primary productivity for the plant functional type. The time-evolving plant conditions are directly affected by and provide an influence on the local energy and water budget in an interactive fashion (Ivanov et al., 2008a, 2008b). Simulated soil water content (SWC), surface energy fluxes $\left(\mathrm{R}_{\text {net }}, \mathrm{H}\right.$ and LE), total evapotranspiration (ET) and leaf area index (LAI), among others, depend on local meteorological conditions, soil properties and plant functional traits obtained via local measurements or parameterized through a model calibration and validation procedure. Overall, tRIBS-VEGGIE simulates the dynamic feedbacks between vegetation and its surrounding environment at differing time scales, explicitly represented starting at the scale of a few minutes (e.g. resolving canopy leaf temperatures), to hourly resolution (e.g. stomatal dynamics) and up to the daily scale processes (e.g. plant phenology and leaf turnover). Ivanov et al. (2008a, 2008b) provide additional details on the model biophysics and its application in other semiarid settings. 


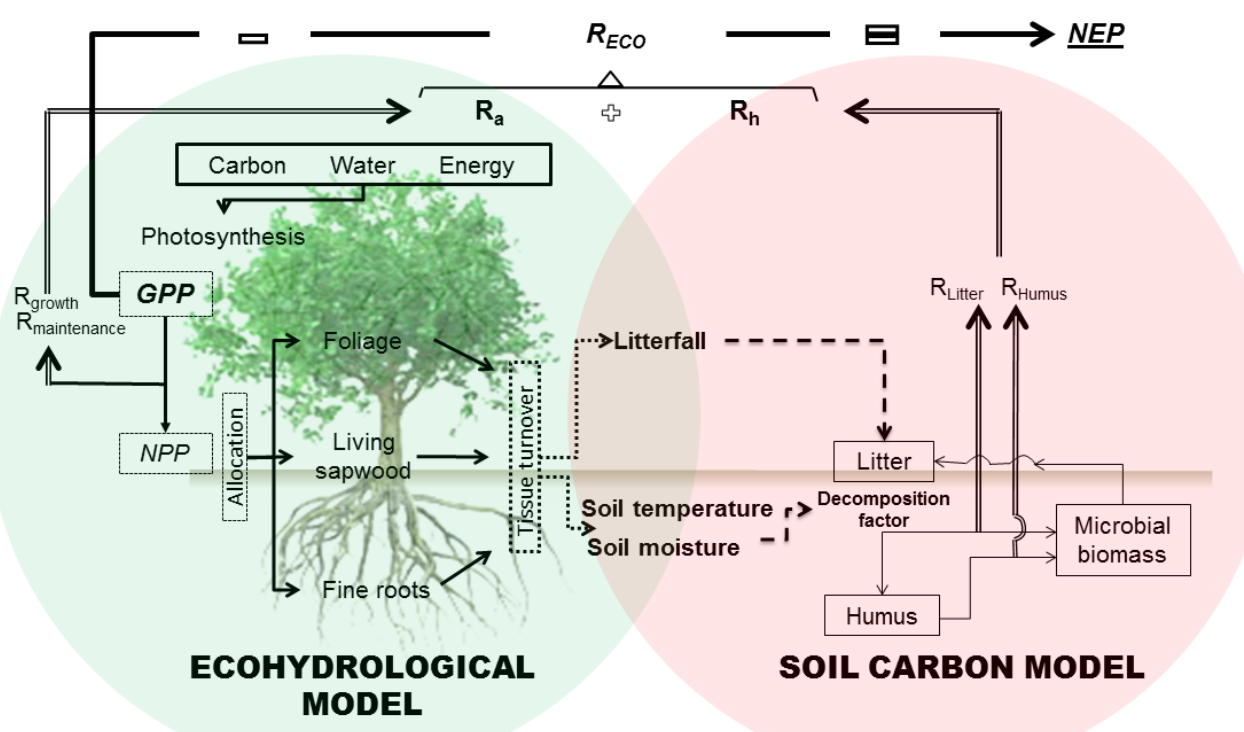

245

246

247

248

249

250

251

252

253

254

255

256

257

258

259

260

261

262

263

Figure 1. Conceptual diagram of model-based estimation of ecosystem carbon fluxes using tRIBS-VEGGIE and SCM. Dotted lines depict ecohydrological model outputs into the soil carbon model, while double lines specify sources of autotrophic, heterotrophic and ecosystem respiration $\left(R_{E C O}=R_{a}+R_{h}\right)$. Net ecosystem productivity (NEP) is obtained as GPP - $R_{E C O}$.

As depicted in Fig. 1, tRIBS-VEGGIE does not simulate soil heterotrophic respiration $\left(\mathrm{R}_{\mathrm{h}}\right)$, limiting its ability to represent net ecosystem productivity $\left(\mathrm{NEP}=\mathrm{GPP}-\mathrm{R}_{\mathrm{a}}-\mathrm{R}_{\mathrm{h}}\right)$. To address this, we implemented a simplified version of the soil carbon model (SCM) of Porporato et al. (2003) based on three separate carbon pools (litter, humus and microbial biomass) to track soil organic matter decomposition and heterotrophic respiration (Bolker et al., 1998; Manzoni et al., 2004; Parolari \& Porporato, 2016). While this approach does not track nitrogen dynamics, we accounted for $\mathrm{C}: \mathrm{N}$ effects on decomposition rates through the use of a heuristic factor $\varphi$ described in Rodríguez-Iturbe \& Porporato (2007) and based values either on local data or magnitudes reported for the region (Martínez-Yrízar et al., 2007; Núñez et al., 2001). Daily carbon pool dynamics simulated in the SCM were driven by soil water content and temperature conditions and the leaf litter production derived from tRIBS-VEGGIE. As a result, the coupling of tRIBS-VEGGIE and SCM allows for the effects of vegetation phenology (i.e. leaf senescence and fall) to impact $\mathrm{R}_{\mathrm{h}}$ and NEP when soil moisture and temperature conditions are favorable. 


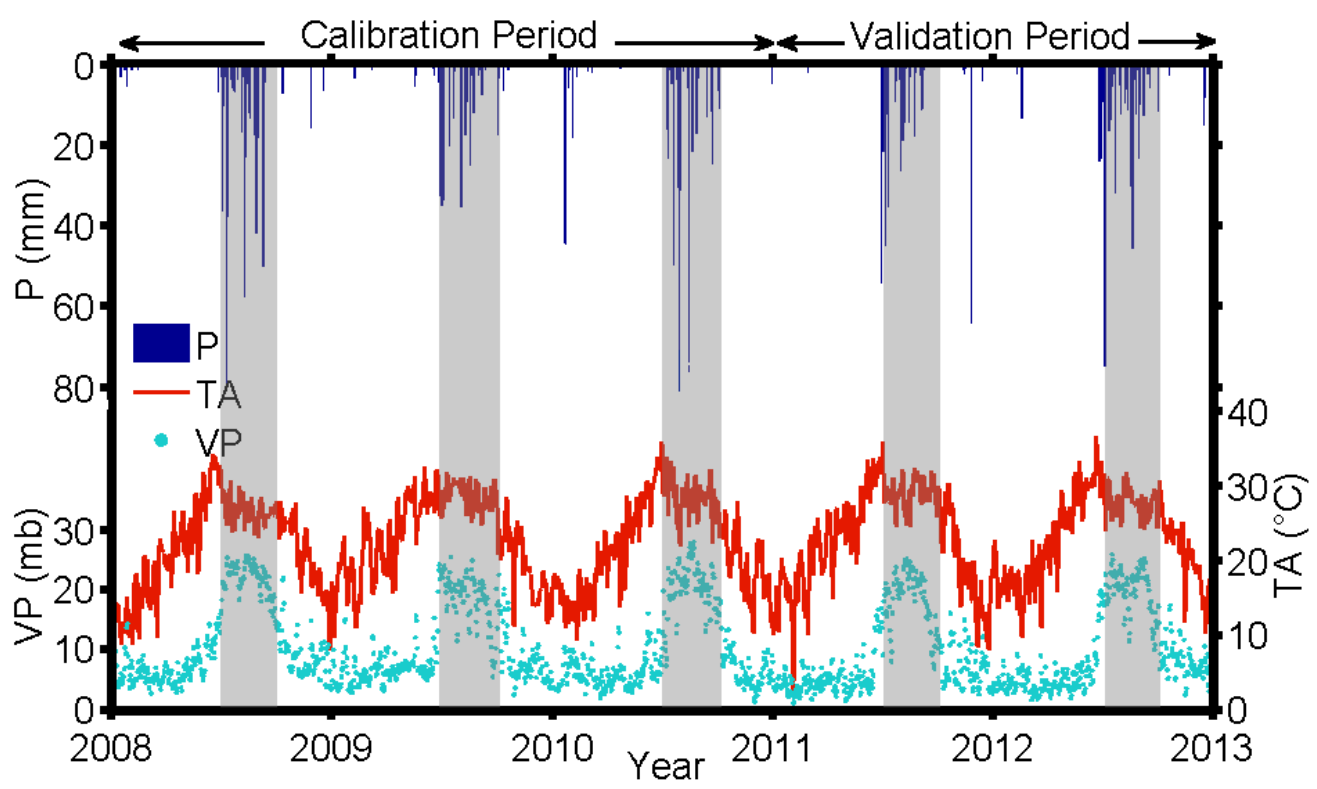

Figure 2. Mean daily meteorological conditions during the study period (2008-2012) consisting of precipitation (P), air temperature (TA) and vapor pressure (VP). Shaded areas represent NAM period (July-September) of each year.

\subsection{Model forcing, parameterization and validation}

Gap-filled meteorological observations over the period 2008-2012 were aggregated to

271 hourly resolution as forcing for tRIBS-VEGGIE and consisted of atmospheric pressure, vapor

272 pressure, air temperature, wind speed, incoming solar and longwave radiation and precipitation.

273 In addition, direct and diffuse radiation components in the visible and near infrared bands and the

274 average atmospheric $\mathrm{CO}_{2}$ concentration during 2008-2012 (390 ppm) were input. Fig. 2 presents

275 an example of the meteorological forcing, illustrating the strong seasonality in precipitation and

276 its corresponding effects on air temperature and vapor pressure during the NAM.

The study period was divided into two subsets for model calibration (2008-2010, 1096

278

279

280

281 days) and validation (2011-2012, 731 days) based upon matching the subset length when

excluding gap-filled periods. While conditions varied to some extent among the subsets, no

trends were noted that would impact model calibration and validation. A similar setup was

carried out for the SCM by using leaf litterfall, soil moisture and soil temperature conditions 
282 obtained from tRIBS-VEGGIE as inputs (Fig. 1). Following Vivoni et al. (2005), the sequence of

283 tRIBS-VEGGIE and SCM simulations were conducted in a periodic fashion by repeating the

284 same 5-yr meteorological forcing 6 times (i.e. total simulation length of 30 years) and retaining

285 the two subsets in the last 5-yr period for model calibration and validation purposes. This

286 initialization approach stabilized soil water content, soil temperature and carbon storage amounts

287 in the vegetation (foliage, sapwood and fine roots) and soil (litter, microbial biomass and humus)

288 pools, thus reducing transient errors in the assignment of the initial conditions.

Initial model parameterization was conducted for tRIBS-VEGGIE and SCM based upon prior efforts with each model (e.g. Bisht, 2010; Ivanov et al., 2008a; Parolari \& Porporato, 2016; Porporato et al., 2003; Sivandran \& Bras, 2012), including applications for the subtropical shrubland (Méndez-Barroso et al., 2014; Vivoni et al., 2010a). For instance, Table 1 presents the soil hydraulic and thermal properties used in tRIBS-VEGGIE for the sandy loam soils at the site whose initial values were obtained through manual calibration conducted by Méndez-Barroso et al. (2014). As in that work, we simplified the modeling of site conditions by treating the soil profile as a uniform sandy loam. In contrast to Méndez-Barroso et al. (2014), however, we applied the one-dimensional Richards equation using a finite element, backward Euler time stepping numerical approximation for infiltration into the unsaturated soil profile (irregular mesh with 25 layers over $1 \mathrm{~m}$ depth), as detailed in Ivanov et al. (2008a). Accordingly, modifications to the soil parameters within feasible ranges based on pedotransfer functions from Rawls et al. (1982) were required to match a larger set of observations (SWC, $\mathrm{R}_{\text {net }}, \mathrm{H}, \mathrm{LE}$ and LAI) over a longer period (i.e. three continuous years in the calibration period). 


\begin{tabular}{cc}
\hline Soil Type & Sandy Loam \\
\hline $\mathbf{K}_{\mathbf{s}}$ & 55 \\
$\boldsymbol{\theta}_{\mathbf{s}}$ & 0.45 \\
$\boldsymbol{\theta}_{\mathbf{r}}$ & 0.02 \\
$\boldsymbol{\lambda}_{\mathbf{o}}$ & 0.47 \\
$\boldsymbol{\psi}_{\mathbf{b}}$ & -90 \\
$\mathbf{k}_{\mathbf{s}, \mathrm{dry}}$ & 0.214 \\
$\mathbf{k}_{\mathbf{s}, \mathbf{s a t}}$ & 2.64 \\
$\mathbf{C}_{\mathbf{s}}$ & 1610586 \\
\hline
\end{tabular}

305

306

307

308

309

310

311

312

313

Table 1. Soil Parameters. $\mathrm{K}_{\mathrm{s}}\left(\mathrm{mm} \mathrm{hr}^{-1}\right)$, surface hydraulic conductivity; $\theta_{\mathrm{s}}(-)$, saturated moisture content; $\theta_{\mathrm{r}}(-)$, residual moisture content; $\lambda_{\mathrm{o}}(-)$, pore size distribution index; $\psi_{\mathrm{b}}(\mathrm{mm})$, air entry bubbling pressure; $\mathrm{k}_{\mathrm{s}, \text { dry }}$ and $\mathrm{k}_{\mathrm{s}, \mathrm{sat}}\left(\mathrm{J} \mathrm{m}^{-1} \mathrm{~s}^{-1} \mathrm{~K}^{-1}\right)$, heat conductivity for dry and saturated soils; $\mathrm{C}_{\mathrm{s}}\left(\mathrm{J} \mathrm{m}^{-3} \mathrm{~K}^{-1}\right)$, heat capacity of dry soils.

(2014). In addition, tRIBS-VEGGIE required a larger set of model parameters to describe

biochemical, biophysical, interception, phenological, carbon allocation and water uptake

processes (Ivanov et al., 2008a). Table 2 lists the final parameter values for vegetation processes

and indicates their sources as either from literature $(\mathrm{L})$, observation $(\mathrm{O})$ or calibration $(\mathrm{C})$.

\begin{tabular}{|c|c|c|}
\hline Parameter & Value & Source \\
\hline \multicolumn{3}{|c|}{ Biochemical Processes } \\
\hline $\mathbf{V}_{\max 25}$ & 50 & $\mathrm{C}$ \\
\hline $\mathbf{K}$ & 0.2 & $\mathrm{C}$ \\
\hline $\mathbf{M}$ & 9 & $\mathrm{~L}$ \\
\hline $\mathbf{B}$ & 10000 & $\mathrm{~L}$ \\
\hline$\varepsilon_{3,4}$ & 0.08 & $\mathrm{~L}$ \\
\hline $\mathbf{r}_{\text {sapw }}$ & $9.61 \times 10^{-10}$ & $\mathrm{~L}$ \\
\hline $\mathbf{r}_{\text {root }}$ & 1. $09 \times 10^{-8}$ & $\mathrm{~L}$ \\
\hline $\mathbf{w}_{\text {grw }}$ & 0.25 & $\mathrm{~L}$ \\
\hline $\mathbf{d}_{\text {leaf }}$ & 1 & $\mathrm{~L}$ \\
\hline $\mathbf{d}_{\text {sapw }}$ & 0.04 & $\mathrm{~L}$ \\
\hline $\mathbf{d}_{\text {root }}$ & 0.33 & $\mathrm{~L}$ \\
\hline \multicolumn{3}{|c|}{ Biophysical and Interception Processes } \\
\hline$\chi \mathbf{L}$ & 0.01 & $\mathrm{~L}$ \\
\hline$\alpha_{\text {leaf }}($ VIS, NIR) & $0.1,0.45$ & $\mathrm{~L}$ \\
\hline$\alpha_{\text {stem }}($ VIS, NIR $)$ & $0.16,0.39$ & $\mathrm{~L}$ \\
\hline$\tau_{\text {leaf }}($ VIS, NIR $)$ & $0.05,0.25$ & $\mathrm{~L}$ \\
\hline$\tau_{\text {stem }}($ VIS, NIR $)$ & $0.001,0.001$ & $\mathrm{~L}$ \\
\hline $\mathbf{K}_{\mathbf{c}}$ & 0.18 & $\mathrm{~L}$ \\
\hline $\mathbf{g}_{\mathbf{c}}$ & 3.9 & $\mathrm{~L}$ \\
\hline
\end{tabular}




\begin{tabular}{ccc}
\hline $\mathbf{S}_{\text {la }}$ & 0.011 & $\mathrm{O}$ \\
\hline \multicolumn{2}{c}{ Phenology, Allocation and } & Uptake Processes \\
\hline$\gamma \mathbf{W}_{\text {max }}$ & 10 & $\mathrm{C}$ \\
$\mathbf{b}_{\mathbf{w}}$ & 2.5 & $\mathrm{C}$ \\
$\gamma \mathbf{C}_{\mathbf{m a x}}$ & 7 & $\mathrm{C}$ \\
$\mathbf{b}_{\mathbf{c}}$ & 1 & $\mathrm{C}$ \\
$\mathbf{T}_{\text {cold }}$ & 15 & $\mathrm{C}$ \\
$\mathbf{e}_{\text {leaf }}$ & 0.25 & $\mathrm{~L}$ \\
$\mathbf{e}_{\text {sapw }}$ & 0.1 & $\mathrm{~L}$ \\
$\mathbf{e}_{\text {root }}$ & 0.65 & $\mathrm{~L}$ \\
$\boldsymbol{\omega}$ & 0.8 & $\mathrm{~L}$ \\
$\boldsymbol{\varepsilon}_{\mathbf{s}}$ & 2 & $\mathrm{~L}$ \\
$\boldsymbol{\xi}$ & 1.6 & $\mathrm{~L}$ \\
$\mathbf{T}_{\text {soil }}$ & 20 & $\mathrm{C}$ \\
$\mathbf{D}_{\mathbf{L H}}$ & 10 & $\mathrm{~L}$ \\
$\mathbf{D}_{\text {Tmin,Fav }}$ & 6 & $\mathrm{C}$ \\
$\mathbf{f}_{\mathbf{c}, \text { init }}$ & 0.025 & $\mathrm{~L}$ \\
$\mathbf{L}_{\text {init }}$ & 0.22 & $\mathrm{~L}$ \\
$\boldsymbol{\psi}^{*}$ & -0.1 & $\mathrm{C}$ \\
$\boldsymbol{\psi}_{\mathbf{w}}$ & -5 & $\mathrm{C}$ \\
\hline
\end{tabular}

Table 2. Vegetation Parameters. $\mathrm{V}_{\max 25}\left(\mu \mathrm{mol} \mathrm{CO}_{2} \mathrm{~m}^{-2}\right.$ leaf s $\left.{ }^{-1}\right)$ is the maximum catalytic capacity of Rubisco at $25^{\circ} \mathrm{C}$; $\mathrm{K}(-)$ is the time-mean PAR extinction coefficient parameterizing the decay of nitrogen content in the canopy; $\mathrm{m}(-)$ is an empirical slope parameter; $\mathrm{b}\left(\mathrm{mmol} \mathrm{m}^{-2} \mathrm{~s}^{-1}\right)$ is the minimum stomatal conductance; $\varepsilon_{3,4}\left(\mu \mathrm{mol} \mathrm{CO}_{2} \mu \mathrm{mol}^{-1}\right.$ photons) is the intrinsic quantum efficiency for $\mathrm{CO}_{2}$ uptake; $\mathrm{r}_{\text {sapw }}$ and $\mathrm{r}_{\text {root }}\left(\mathrm{g} \mathrm{C} \mathrm{g} \mathrm{C}^{-1} \mathrm{~s}^{-1}\right)$ are the sapwood and fine root respiration coefficients at $10^{\circ} \mathrm{C} ; \mathrm{w}_{\mathrm{grw}}(-)$ is the fraction of canopy assimilation less maintenance respiration used for tissue growth; $d_{\text {leaf }}, d_{\text {sapw }}$ and $d_{\text {root }}\left(\mathrm{yr}^{-1}\right)$ are the turnover rates for leaf, sapwood and roots; $\chi \mathrm{L}(-)$ is the departure of leaf angles from a random distribution; $\alpha_{\text {leaf }}$ and $\alpha_{\text {stem }}(-)$ are the leaf and stem reflectances in the VIS and NIR bands; $\tau_{\text {leaf }}$ and $\tau_{\text {stem }}(-)$ are leaf and stem transmittances in the VIS and NIR bands; $\mathrm{K}_{\mathrm{c}}\left(\mathrm{mm} \mathrm{hr}^{-1}\right)$ is the canopy drainage coefficient, $\mathrm{g}_{\mathrm{c}}\left(\mathrm{mm}^{-1}\right)$ is the exponential decay parameter of canopy water drainage; $\mathrm{S}_{\mathrm{la}}\left(\mathrm{m}^{2}\right.$ leaf area $\left.\mathrm{kg} \mathrm{C}^{-1}\right)$ is the specific leaf area; $\gamma \mathrm{W}_{\max }$ and $\gamma \mathrm{C}_{\max }\left(\right.$ day $\left.^{-1}\right)$ are maximum drought and cold-induced foliage loss rates; $b_{\mathrm{W}}$ and $b_{\mathrm{C}}(-)$ are the shape parameters reflecting the sensitivity of canopy to drought and cold; $\mathrm{T}_{\text {cold }}\left({ }^{\circ} \mathrm{C}\right)$ is the temperature threshold below which cold-induced leaf loss begins; $\mathrm{e}_{\text {leaf }}, \mathrm{e}_{\text {sapw }}$ and $\mathrm{e}_{\mathrm{root}}(-)$ are the base allocation fractions for leaf, sapwood and roots; $\omega(-)$ is the sensitivity parameter of allocation fractions to changes in light and water availability; $\varepsilon_{\mathrm{s}}$ and $\xi(-)$ are parameters controlling the relation between carbon content in the above and below ground biomass; $\mathrm{T}_{\text {soil }}\left({ }^{\circ} \mathrm{C}\right)$ and $\mathrm{D}_{\mathrm{LH}}(\mathrm{hr})$ are the mean daily soil temperature and day length to be exceeded for the growing season start; $\mathrm{D}_{\mathrm{Tmin}, \mathrm{Fav}}(\mathrm{day})$ is the minimum duration for which the conditions of transition from/to the dormant season have to be continuously met; $f_{c, \text { init }}$ and $L_{\text {init }}(-)$ are the fraction of the structural biomass and leaf area index used to initiate leaf onset; $\psi^{*}$ and $\psi_{\mathrm{w}}(\mathrm{MPa})$ are the soil matric potentials at which the stomatal closure and plant wilting begins. 


\begin{tabular}{ccc}
\hline Parameter & Value & Source \\
\hline $\mathbf{C}_{\mathbf{l}}$ & 89 & $\mathrm{~L}$ \\
$\mathbf{C}_{\mathbf{h}}$ & 895 & $\mathrm{~L}$ \\
$\mathbf{C}_{\mathbf{b}}$ & 25 & $\mathrm{~L}$ \\
$\mathbf{C} / \mathbf{N}_{\text {litter }}$ & 23 & $\mathrm{O}$ \\
$\mathbf{C} / \mathbf{N}_{\text {humus }}$ & 22 & $\mathrm{~L}$ \\
$\mathbf{C} / \mathbf{N}_{\text {biomass }}$ & 8 & $\mathrm{~L}$ \\
$\mathbf{r}_{\mathbf{h}}$ & 0.003 & $\mathrm{~L} / \mathrm{C}$ \\
$\mathbf{r}_{\mathbf{r}}$ & 0.65 & $\mathrm{~L}$ \\
$\mathbf{k}_{\mathbf{b}}$ & 0.0000988 & $\mathrm{C}$ \\
$\mathbf{k}_{\mathbf{h}}$ & $2.1 \times 10^{-7}$ & $\mathrm{C}$ \\
$\mathbf{k}_{\mathbf{l}}$ & 0.00107 & $\mathrm{C}$ \\
\hline
\end{tabular}

338

339

340

341

342

343

344

345

346

347

348

349

350

351

352

353

354

355

356

357

Table 3. Soil Decomposition Parameters. $C_{l}, C_{h}$ and $C_{b}\left(\mathrm{~g} \mathrm{C} \mathrm{m}^{-2}\right)$ are initial carbon concentrations in the litter, humus and biomass pools; $\mathrm{C} / \mathrm{N}_{\text {litter }}, \mathrm{C} / \mathrm{N}_{\text {humus }}$ and $\mathrm{C} / \mathrm{N}_{\text {biomass }}(-)$ are carbon-nitrogen ratios of litter, humus and biomass; $r_{h}$ and $r_{f}(-)$ are fractions of organic matter undergoing humification and of decomposed organic carbon that is respired; $\mathrm{k}_{\mathrm{l}}, \mathrm{k}_{\mathrm{h}}$ and $\mathrm{k}_{\mathrm{b}}\left(\mathrm{hr}^{-1}\right)$ are first-order kinetic constants of litter, humus and biomass.

Manual calibration of vegetation parameters focused on capturing the LAI dynamics during 2008-2010 as observed from MODIS during the NAM growing season. A one-at-a-time sensitivity analysis was conducted to identify the importance of each parameter on the simulation of LAI and limit the sampling necessary for model calibration. Similarly, a manual calibration approach was used for the SCM parameters (Table 3). We used observations of SCM model parameters or initial conditions when available from the site or nearby areas (e.g. Búrquez et al., 1999; Martínez-Yrízar et al., 1999; 2007; Núñez et al., 2001; Pavón et al., 2005). Though manual calibration was conducted, the combined models are amenable to automated estimation methods (e.g. Duan et al., 1993) due to the low computational demands for single site applications. The combination of tRIBS-VEGGIE and SCM allowed for simulation of $\mathrm{R}_{\mathrm{ECO}}=\mathrm{R}_{\mathrm{a}}+\mathrm{R}_{\mathrm{h}}$ that was compared to $\mathrm{R}_{\mathrm{ECO}}$ observations derived from the EC method during calibration and subsequently permitted a comparison of NEP between observations and simulations. We validated the model performance using a comparison between simulated and observed values of the aforementioned variables during the 2011-2012 period, which was not used in the model calibration effort. 


\subsection{Climate change and $\mathrm{CO}_{2}$ fertilization experiments}

We obtained air temperature (monthly) and precipitation (3-hr) projections from the Coupled Model Intercomparison Project version 5 (CMIP5) (Taylor et al., 2012) for three General Circulation Models (GCMs) selected for their ability to represent the NAM system (Geil et al., 2013): CNRM-CM5, HadGEM2-ES and MIROC5. Single realizations from each model were selected for a near-future period (2030-2045) under the RCP8.5 emissions case (IPCC, from NLDAS (labeled as 'HIST'). Given the hourly meteorological forcing requirements of tRIBS-VEGGIE, we implemented the stochastic downscaling method of Fatichi et al. (2013) to apply a set of factors of change derived from the individual GCMs and their averaged conditions (referred to hereafter as 'AVE') to the statistical properties obtained from the historical forcing. For each scenario, sets of change factors were calculated separately for the statistical properties of precipitation (e.g. mean, variance, skewness and frequency of no-precipitation at different aggregation periods (1, 6, 24, 72 hours) and mean monthly air temperature). Since GCM realizations were obtained at a 3-hr interval, we followed Fatichi et al. (2011) to extend the statistical properties to a finer hourly resolution for the full set of meteorological forcings (atmospheric pressure, wind speed, incoming solar and longwave radiation, air temperature, vapor pressure and precipitation). Since our study periods were relatively short (15-yr), we utilized the derived statistical metrics from the method of Fatichi et al. (2013) to generate synthetic (100-yr long) hourly forcings for each scenario (HIST, CNRM-CM5, HadGEM2-ES, MIROC5 and AVE). These should be considered as representative realizations of the climate system under stationary historical and near-future conditions, as simulated by these GCMs, allowing statistical sampling to be conducted. Two sets of simulations were performed for each 
381 scenario to differentiate the effects of $\mathrm{CO}_{2}$ fertilization from meteorological changes: (1) No

382 fertilization cases used the average of $365 \mathrm{ppm}$ calculated from historical $\mathrm{CO}_{2}$ concentrations

383 from 1990-2005 and (2) $\mathrm{CO}_{2}$ fertilization cases with a constant concentration of $482 \mathrm{ppm}$,

384 obtained from RCP8.5 from 2030-2045 period (about a 32\% increase in $\mathrm{CO}_{2}$ above historical).

385 Since we are simulating synthetic 100-yr long scenarios, it was necessary to use a constant $\mathrm{CO}_{2}$

386 concentration that best represent the conditions for each period (i.e., 1990-2005 and 2030-2045).

387

388

389

390

391

392

393

394

395

396

397

398

399

400

401

402

403

404

\section{Results and discussion}

\subsection{Evaluation of simulated water, energy and carbon dynamics}

Simulated water, energy and carbon states and fluxes in the subtropical shrubland were compared to available observations over the calibration, validation and full study periods using three metrics: correlation coefficient (CC), bias (B) and mean absolute error (MAE) (Vivoni et al., 2006). Table 4 shows the metrics obtained for daily-averaged and hourly values, with a CC near one, a bias close to unity and a low MAE indicating a good match between the observed and simulated variables at both time scales and for all variables. For instance, the simulated surface energy fluxes ( $\mathrm{R}_{\mathrm{net}}, \mathrm{H}$ and $\mathrm{LE}$ ) exhibit a good correspondence to observations, with high CC (> 0.77), B near unity (within \pm 0.16 ) and an MAE less than $33 \mathrm{~W} \mathrm{~m}^{-2}$ for hourly and daily values. Fig. 3 illustrates the model performance with respect to the surface energy fluxes by comparing seasonal cycles of $\mathrm{R}_{\text {net }}, \mathrm{H}$ and $\mathrm{LE}$ over the full study period. Note the dramatic change in the partitioning of $\mathrm{R}_{\text {net }}$ into $\mathrm{H}$ and LE upon the onset of the NAM in July, with the arrival of summer storms increasing LE (or ET) substantially. Overall, the ecohydrological model adequately captures monthly variations in the surface energy fluxes, though a consistent underestimation of $\mathrm{R}_{\text {net }}$ of $14.4 \mathrm{~W} \mathrm{~m}^{-2}$ is noted from December through June due to the lack of simulated vegetation (i.e. a decrease in LAI and a corresponding increase in albedo) affecting the absorption of solar 


\begin{tabular}{|c|c|c|c|c|c|c|c|c|c|c|}
\hline & \multirow[t]{2}{*}{ Variable } & \multicolumn{3}{|c|}{$\begin{array}{c}\text { Calibration period } \\
2008-2010\end{array}$} & \multicolumn{3}{|c|}{$\begin{array}{c}\text { Validation period } \\
2011-2012\end{array}$} & \multicolumn{3}{|c|}{$\begin{array}{c}\text { Full period } \\
2008-2012\end{array}$} \\
\hline & & $\mathbf{C C}$ & B & MAE & $\mathrm{CC}$ & B & MAE & $\mathbf{C C}$ & B & MAE \\
\hline \multirow{9}{*}{ 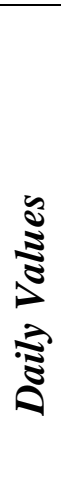 } & $\operatorname{SWC}\left(\mathrm{m}^{3} \mathrm{~m}^{-3}\right)$ & 0.86 & 0.91 & 0.03 & 0.93 & 0.65 & 0.01 & 0.86 & 0.83 & 0.02 \\
\hline & ET (mm) & 0.91 & 0.81 & 0.01 & 0.94 & 0.89 & 0.02 & 0.92 & 0.84 & 0.01 \\
\hline & LAI (-) & 0.88 & 1.06 & 0.39 & 0.91 & 1.00 & 0.36 & 0.89 & 1.04 & 0.38 \\
\hline & $\mathbf{R}_{\text {net }}\left(\mathbf{W} \mathbf{m}^{-2}\right)$ & 0.85 & 0.91 & 19.46 & 0.97 & 0.87 & 15.05 & 0.91 & 0.90 & 17.70 \\
\hline & $\mathbf{L E}\left(\mathbf{W} \mathrm{m}^{-2}\right)$ & 0.91 & 0.81 & 9.22 & 0.94 & 0.89 & 11.2 & 0.92 & 0.84 & 10.01 \\
\hline & $\mathbf{H}\left(\mathbf{W} \mathbf{m}^{-2}\right)$ & 0.76 & 1.16 & 16.88 & 0.82 & 0.91 & 18.16 & 0.77 & 1.04 & 17.39 \\
\hline & GPP $\left(\mathrm{g} \mathrm{C} \mathrm{m}^{-2}\right)$ & 0.85 & 0.92 & 0.04 & 0.83 & 1.16 & 0.04 & 0.85 & 1.05 & 0.04 \\
\hline & $R_{\text {ECO }}\left(\mathrm{g} \mathrm{C} \mathrm{m}^{-2}\right)$ & 0.90 & 1.09 & 0.02 & 0.88 & 1.16 & 0.02 & 0.90 & 1.12 & 0.02 \\
\hline & $\operatorname{NEP}\left(\mathrm{g} \mathrm{C} \mathrm{m}^{-2}\right)$ & 0.58 & 0.99 & 0.03 & 0.67 & 0.95 & 0.03 & 0.60 & 0.78 & 0.03 \\
\hline \multirow{8}{*}{ 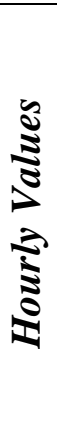 } & $\operatorname{SWC}\left(\mathrm{m}^{3} \mathrm{~m}^{-3}\right)$ & 0.80 & 0.91 & 0.03 & 0.90 & 0.65 & 0.01 & 0.81 & 0.83 & 0.02 \\
\hline & ET (mm) & 0.86 & 0.81 & 0.02 & 0.79 & 0.88 & 0.03 & 0.83 & 0.84 & 0.03 \\
\hline & $\mathbf{R}_{\text {net }}\left(\mathbf{W} \mathbf{m}^{-2}\right)$ & 0.96 & 0.91 & 28.23 & 0.97 & 0.87 & 31.33 & 0.96 & 0.90 & 29.47 \\
\hline & $\mathbf{L E}\left(\mathbf{W} \mathbf{m}^{-2}\right)$ & 0.86 & 0.81 & 15.98 & 0.79 & 0.88 & 22.2 & 0.83 & 0.84 & 18.48 \\
\hline & $\mathbf{H}\left(\mathbf{W} \mathbf{m}^{-2}\right)$ & 0.90 & 1.16 & 24.65 & 0.91 & 0.91 & 45.33 & 0.90 & 1.04 & 32.92 \\
\hline & $\operatorname{GPP}\left(\mathrm{g} \mathrm{C} \mathrm{m}^{-2}\right)$ & 0.70 & 1.08 & 0.07 & 0.75 & 1.29 & 0.05 & 0.72 & 1.15 & 0.06 \\
\hline & $R_{\text {ECO }}\left(g_{\text {C m }}^{-2}\right)$ & 0.73 & 1.09 & 0.04 & 0.69 & 1.16 & 0.04 & 0.71 & 1.12 & 0.04 \\
\hline & $\operatorname{NEP}\left(\mathrm{g} \mathrm{C} \mathrm{m}^{-2}\right)$ & 0.58 & 0.97 & 0.07 & 0.63 & 0.94 & 0.06 & 0.60 & 0.78 & 0.06 \\
\hline
\end{tabular}

405

406

407

408

409

410

411

412

413

414

415

416

417

418

419
Table 4. Model Performance Metrics for Daily and Hourly Values. Correlation coefficient (CC), Bias (B) and Mean Absolute Error (MAE) are calculated for soil water content (SWC), evapotranspiration (ET), leaf area index (LAI), net radiation $\left(\mathrm{R}_{\text {net }}\right)$, sensible heat flux $(\mathrm{H})$, gross primary productivity $(\mathrm{GPP})$, ecosystem respiration $\left(\mathrm{R}_{\mathrm{ECO}}\right)$ and net ecosystem productivity (NEP) during calibration, validation and full periods.

radiation, comparable to prior studies (Ivanov et al., 2008a). In addition, tRIBS-VEGGIE

simulation tends to slightly overestimate sensible heat flux from May to August by an average of $12.7 \pm 3.8 \mathrm{~W} \mathrm{~m}^{-2}$, despite adequately capturing the latent heat flux, though the difference is within the monthly standard deviation (error bars) obtained across all years. Overall, monthly, daily and hourly comparisons demonstrate the robust capability of tRIBS-VEGGIE to capture surface energy fluxes, themselves tied to soil water content and vegetation conditions.

Fig. 4 presents observed and simulated SWC in the top $10 \mathrm{~cm}$, LAI dynamics and litterfall variations during the calibration and validation periods, and simulated soil temperature $\left(\mathrm{T}_{\text {soil }}\right)$ derived from tRIBS-VEGGIE that are critical inputs to the SCM. Note how the summer rainy 


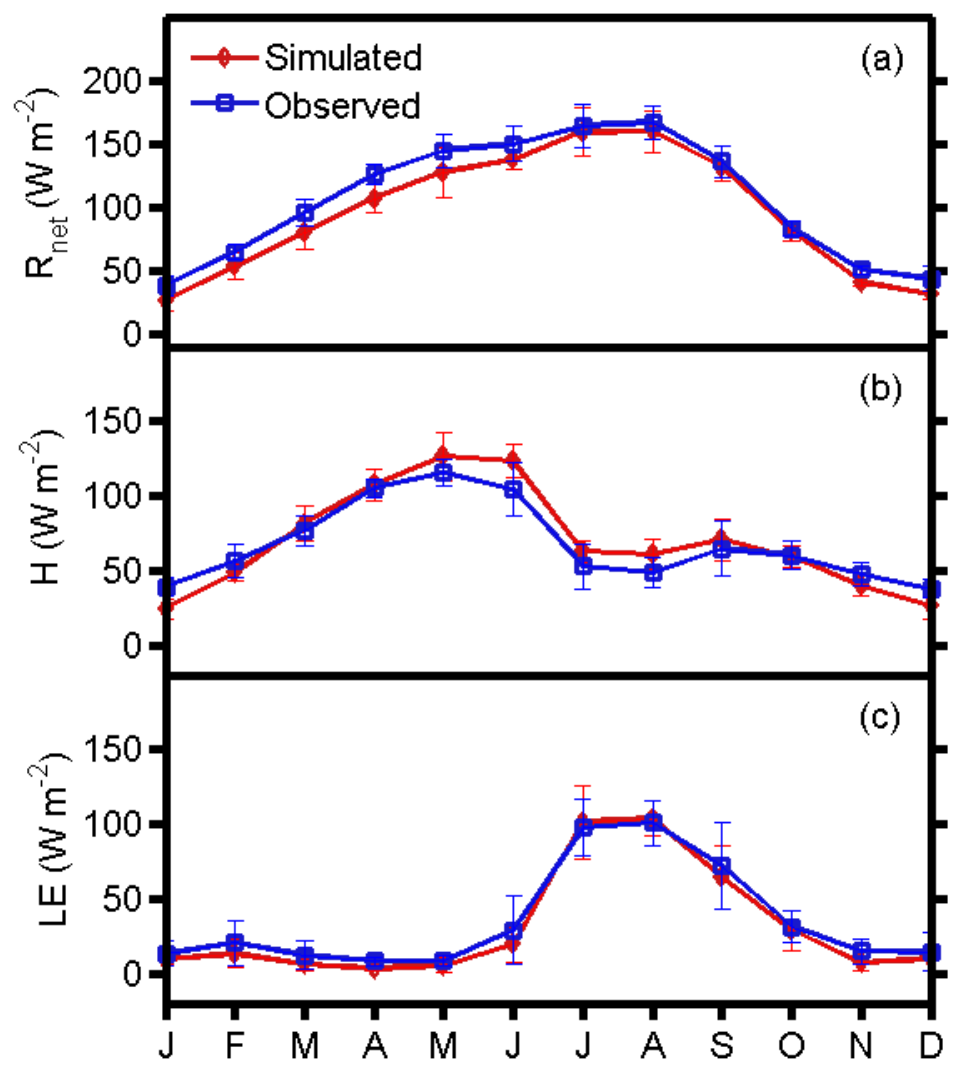

Figure 3. Seasonal cycle of observed versus simulated surface energy fluxes over the study period (2008-2012): (a) net radiation $\left(\mathrm{R}_{\text {net }}\right)$, (b) sensible heat flux $(\mathrm{H})$ and (c) latent heat flux (LE). Symbols are monthly averages and \pm 1 standard deviation as error bars.

season during the NAM leads to increases in SWC that were accurately captured by the model, as described in Table 4, with the tRIBS-VEGGIE model serving as an effective tool to interpolate within periods of observed data gaps. Simulated LAI captured well the primary summer growing season $(\mathrm{CC} \geq 0.88$, B within 0.06 of unity, MAE $\leq 0.39)$ and the differences between years. However, the model did not capture the observed (MODIS-based) LAI variations during the winter period, as noted by Bisht (2010). This is likely due to representing only the drought-deciduous component of the ecosystem (C3 shrubland) and possible issues related to the scale discrepancy between MODIS-based LAI estimates and the model application. Although this might lead to small errors in the estimation of annual biomass, the particularly strong summer season minimizes the role played by the winter in terms of physiological activity, as has 
435 been noted with carbon fluxes in the NAM region (e.g. Huxman et al., 2004b; Pérez-Ruiz et al., 2010; Scott et al., 2004; Verduzco et al., 2015). Correspondingly, model estimates of GPP were

437 adequate at the hourly resolution as compared to derived values from the EC measurements and 438 improved substantially at the daily resolution (Table 4), though we noted that overestimation 439 during the NAM was typical $(\mathrm{B}=1.23)$. Although LAI and the foliage carbon pool appears to 440 have low interannual variations, the simulations of GPP that account for all carbon pools (root, 441 stem and foliage) correspond well with observations and demonstrate higher values during wetter 442 years, as expected. The few available data on $\mathrm{T}_{\text {soil }}$ limited the possible tests of the model, though 443 for 2011, tRIBS-VEGGIE matched the observations very well $(\mathrm{CC}=0.97, \mathrm{~B}=0.99$ and $\mathrm{MAE}=$ $444 \quad 1.9{ }^{\circ} \mathrm{C}$ for hourly values).

After the NAM ends, soil moisture and temperature conditions become less favorable for the drought-deciduous plants and the subtropical shrubland transitioned into dormancy (low LAI 447 by November) after a complete foliage turnover (Fig. 4). Litterfall was simulated by tRIBS-

448 VEGGIE to account for about $30 \%$ of the GPP each year, with values ranging from 120 to $180 \mathrm{~g}$ $449 \mathrm{C} \mathrm{m}^{-2} \mathrm{yr}^{-1}$, consistent with studies in the Sonoran Desert $\left(\sim 157 \mathrm{~g} \mathrm{C} \mathrm{m}^{-2} \mathrm{yr}^{-1}\right)$ (Martínez-Yrízar et 450 al., 1999). Along with the simulated $\mathrm{SWC}$ and $\mathrm{T}_{\text {soil }}$ conditions, litterfall determined inputs to the 451 SCM from which heterotrophic respiration $\left(R_{h}\right)$ fluxes were simulated (Fig. 4b). Simulated 452 carbon amounts in the litter and microbial biomass pools ranged from 20 to $200 \mathrm{~g} \mathrm{C} \mathrm{m}^{-2}$ and 453 from 70 to $130 \mathrm{~g} \mathrm{C} \mathrm{m}^{-2}$, respectively, whereas the carbon amount in the humus pool remained 454 relatively stable at $895-900 \mathrm{~g} \mathrm{C} \mathrm{m}^{-2}$ during the study period, similar to measured values in 455 semiarid shrublands (e.g. Bolton et al., 1993; Cardoso et al., 2015; Cheng et al., 2015; Goberna 456 et al., 2007). As expected, low amounts of $R_{h}$ occur during the winter and spring and increase 457 substantially after the first rainfall event during the NAM due to the available SWC and labile 


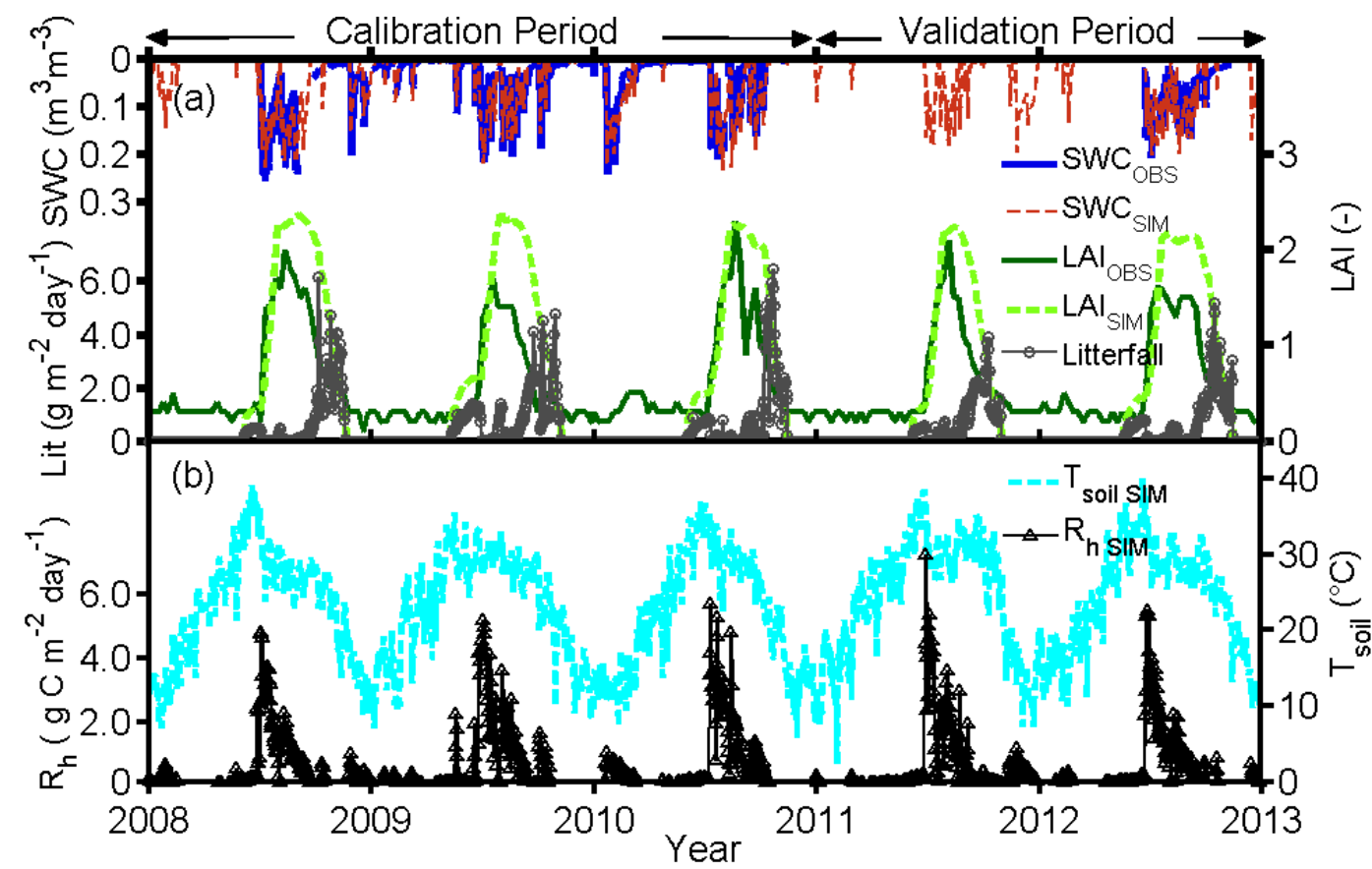

Figure 4. (a) Comparison of daily observed (OBS) and simulated (SIM) soil water content (SWC) and leaf area index (LAI). Simulated Litterfall (Lit) in (a), soil temperature $\left(\mathrm{T}_{\text {soil }}\right)$ and heterotrophic respiration $\left(\mathrm{R}_{\mathrm{h}}\right)$ in (b) from tRIBS-VEGGIE (Litterfall, $\left.\mathrm{T}_{\text {soil }}\right)$ and SCM $\left(\mathrm{R}_{\mathrm{h}}\right)$.

substrate, consistent with Verduzco et al. (2015) and Zhang et al. (2014). Simulated litter decomposition decreased as the labile substrate amounts were depleted which leads to a reduction in the microbial biomass pool, similar to observations made in long-term incubation studies (Follett et al., 2007; Steinweg et al., 2008). As a result, the heterotrophic respiration was highly sensitive to the arrival of early storms during the NAM warm season, through its impact on SWC, and to the amount of labile substrate from the previous summer season, via the litterfall occurring at the end of the prior NAM.

By capturing $R_{h}$ in the $S C M$, the simulated ecosystem respiration $\left(R_{E C O}=R_{a}+R_{h}\right)$ was

471 compared to EC measurements in Fig. 5. Table 4 indicates a good correspondence between the

472 observed and simulated $\mathrm{R}_{\mathrm{ECO}}\left(\mathrm{CC}>0.73\right.$, B within 0.09 of unity, $\left.\mathrm{MAE}<0.04 \mathrm{~g} \mathrm{C} \mathrm{m}^{-2}\right)$ at hourly

473 and daily resolution. However, we noted discrepancies in the $\mathrm{R}_{\mathrm{ECO}}$ for summers with high LAI,

474 suggesting that autotrophic respiration $\left(\mathrm{R}_{\mathrm{a}}\right)$ for plant growth and maintenance was overestimated

475 to some extent. In addition, simulated $\mathrm{R}_{\mathrm{ECO}}$ appeared flashier than the observations at the start of 


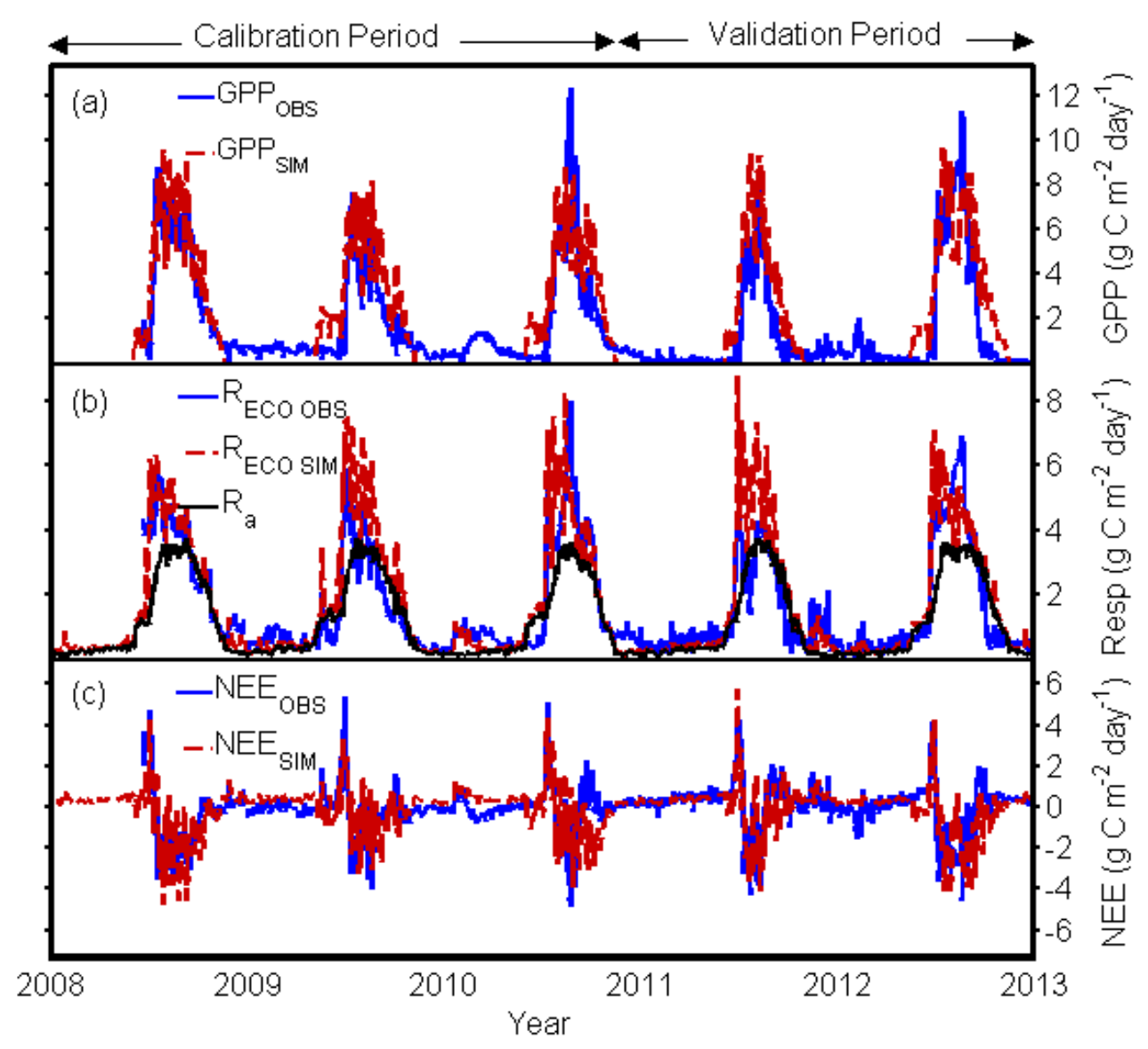

476

477

478

479

480

481

482

483

484

485

486

487

488

489

490

Figure 5. Comparison of observed (OBS) versus simulated (SIM) of (a) gross primary productivity, (b) ecosystem respiration $\left(\mathrm{R}_{\mathrm{ECO}}\right)$ along with simulated autotrophic respiration $\left(\mathrm{R}_{\mathrm{a}}\right)$ and, (c) net ecosystem exchange. Simulated $R_{E C O}$ was obtained by combining $R_{a}$ from the ecohydrological model tRIBS-VEGGIE and $\mathrm{R}_{\mathrm{h}}$ from the SCM.

the summer season (Fig. 5b) due to rapid changes in $\mathrm{R}_{\mathrm{h}}$ when both labile substrate and water were available and soil temperatures are high. As expected, the contribution of $R_{h}$ to $R_{E C O}$ decreased while the contribution of $\mathrm{R}_{\mathrm{a}}$ increased during the temporal progression of the NAM season, reflecting the reduced role of microbial decomposition and the increased role of plant respiration during the growing period (e.g. Carbone et al., 2016).

Fig. 5 and Table 4 also compare observed and simulated GPP, NEE and NEP, respectively, indicating a reasonable match at hourly and daily scales. Note that the positive NEE (carbon loss) occurring early in the summer would not have been possible to represent without simulating $\mathrm{R}_{\mathrm{h}}$ in the SCM, consistent with the metabolic activity of microbial communities when 
high quality litter inputs were available (Carbone et al., 2011; McCulley et al., 2004; Sponseller, 2007; Thiessen et al., 2013; Unger et al., 2010). Furthermore, the negative NEE (carbon uptake) during the growing season and the stable values of NEE near zero during the dormant period were accurately captured by the models. Some issues are noted in 2010 which has an observed positive NEE in the late summer season that is not reproduced by the models. Nevertheless, similar patterns of annual NEP were found in the simulations and observations. During the study period, the subtropical shrubland acted as a net sink of carbon during most years (annual NEP from 33 to $105 \mathrm{~g} \mathrm{C} \mathrm{m}^{-2}$ ), with the exception of 2011, in which both the simulations and observations indicated a net source of carbon (NEP of -53.1 and $-98.3 \mathrm{~g} \mathrm{C} \mathrm{m}^{-2}$ ).

\subsection{Meteorological changes in historical and climate change experiments}

Fig. 6 presents the outcomes of the stochastic downscaling procedure applied to historical (1990-2005, NLDAS) and near-future (2030-2045, CNRM-CM5, HadGEM2-ES, MIROC5 and AVE) periods in terms of the seasonal (monthly) cycle of air temperature and precipitation (a, b) and the probability density functions (PDFs) of summertime TA and P (c, d). These metrics were selected to show the range of meteorological changes in the experiments and summarize the model forcing tailored to the study site (i.e. a full set of hourly variables of 100 -yr duration for each scenario). Due to the model performance and the nature of the seasonal dynamics, a focus is placed on the summer season (MJJAS) in the analyses, including a distinction between premonsoon (MJ) and monsoon (JAS) periods. As expected from the RCP8.5 emissions case, a strong warming signal is present in the near-future, with increases in mean annual temperature ranging from +1.1 to $+2.3{ }^{\circ} \mathrm{C}$ with respect to the HIST scenario. HadGEM2-ES exhibited the largest increase in mean summer TA $\left(+2.6^{\circ} \mathrm{C}\right)$, whereas CNRM-CM5 had the lowest increase $\left(+1.0^{\circ} \mathrm{C}\right)$ relative to HIST. When averaged over the three models, the AVE scenario indicates a 
warming of $+1.7{ }^{\circ} \mathrm{C}$ in mean summer TA and a shift from a range of 24.4 to $33.6^{\circ} \mathrm{C}$ in HIST $( \pm 1$ standard deviation envelop) to 26.1 to $35.3{ }^{\circ} \mathrm{C}$ in AVE (Fig. 6a). These effects are illustrated nicely through the PDFs of summer (MJJAS) average TA, obtained from hourly values over the 100-yr sample size (Fig. 6c). Note the increase in summer TA relative to HIST in the order: CNRM-CM5, MIROC5 and HadGEM2-ES. These estimates are consistent with projections for the North American monsoon (Cook \& Seager, 2013; Lee \& Wang, 2014; Maloney et al., 2014; Pachauri et al., 2014) suggesting a warming signal of +1.4 and $2.7^{\circ} \mathrm{C}$ between 2035 and 2065 . A comparison of the seasonal cycle of precipitation from the scenarios (Fig. 6b) indicates that the use of factors of change in the stochastic downscaling method preserves rainfall seasonality as compared to the historical period with 60 to $80 \%$ of the annual precipitation occurring during summer (MJJAS), while leading to the differences in mean summer precipitation amounts (Fig. 6d). Among the GCMs, HadGEM2-ES had lowest mean summer precipitation in the near-future period ( $327 \mathrm{~mm}$ or $-21 \mathrm{~mm}$ with respect to HIST), whereas MIROC5 exhibited the highest mean summer $\mathrm{P}(422 \mathrm{~mm}$ or $+74 \mathrm{~mm}$ relative to HIST). When averaged over the three models, the AVE scenario had a nearly identical mean monthly variation of P as HIST (Fig. 6b), with a slightly expanded range of variability in August and October, and a similar distribution of summer total P (Fig. 6d). These comparisons are important since relative precipitation differences among GCMs (i.e. two GCMs have lower $\mathrm{P}$ and one has a higher $\mathrm{P}$ as compared to HIST) were quite larger than their temperature variations (i.e. all GCMs show rising TA). Precipitation variations in the scenarios might differ from other analysis of the CMIP5 models (Cook \& Seager, 2013) or other downscaling approaches applied to the NAM region (Castro et al., 2012; Cerezo-Mota et al., 2011) since the historical seasonality at a monthly 

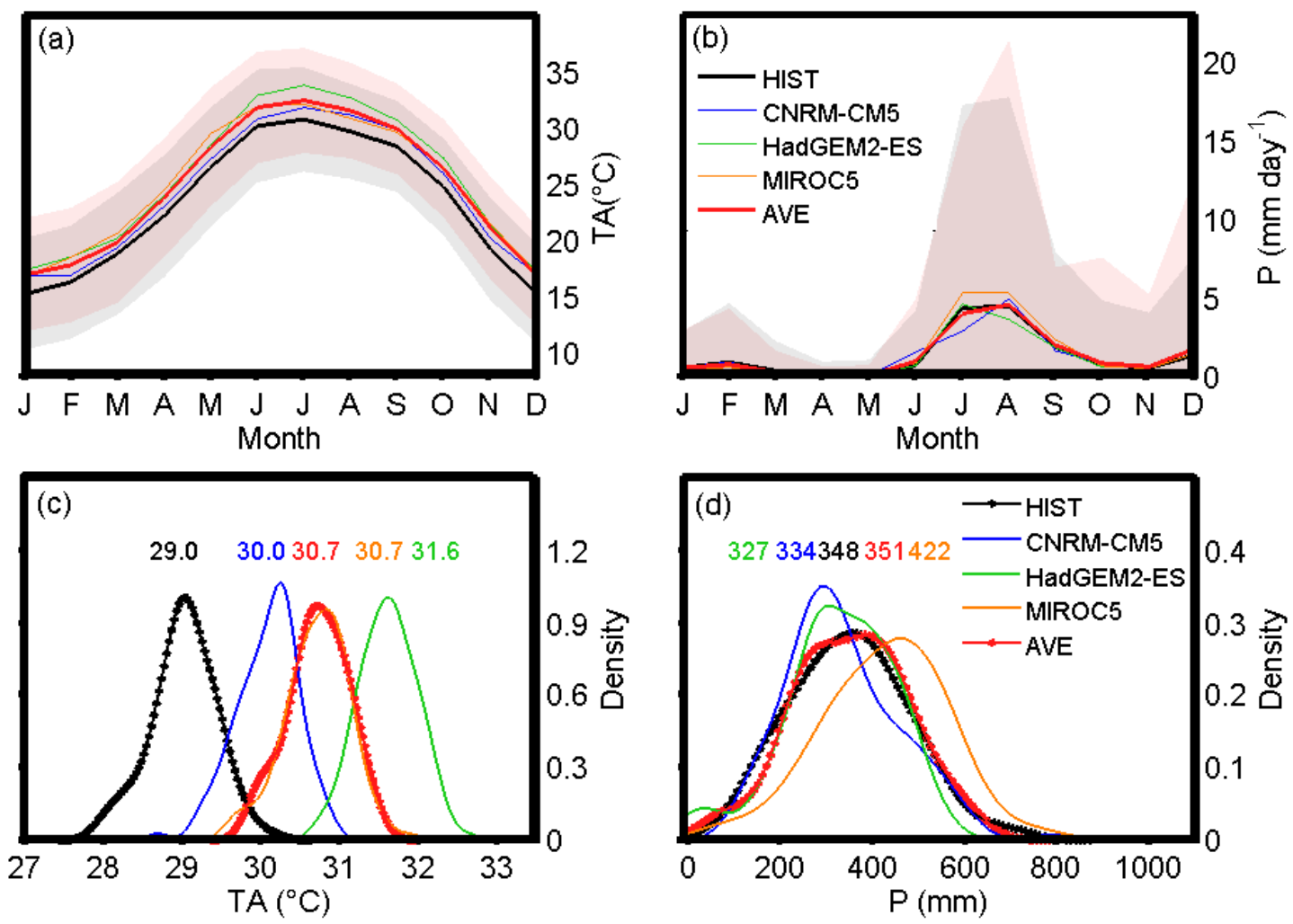

Figure 6. Comparison of meteorological conditions for historical (1990-2005) and climate change experiments (2030-2045) at the study site using representative realizations for HIST, CNRM-CM5, HadGEM2-ES, MIROC5 and AVE. (a, b) Monthly averages of daily air temperature (TA) and precipitation $(\mathrm{P})$ with \pm 1 standard deviation shown as a shaded envelope for HIST (gray) and AVE (pink). (c, d) Probability density functions (PDFs) of summer (MJJAS) average TA and total P. Numbers indicate mean values for each case.

resolution was explicitly preserved, rather than allowed to evolve dynamically in the stochastic downscaling approach applied (Fatichi et al., 2013). Nevertheless, the considered scenarios captured a range of plausible near-future precipitation conditions, including increasing, decreasing or no net change in summer amounts, under a warming trend that are considered realistic for the purposes of identifying climate change impacts.

\subsection{Meteorological change effects on simulated water, energy and carbon dynamics}

Responses to meteorological variations imposed by the climate change experiments were assessed first in the absence of increases in atmospheric $\mathrm{CO}_{2}$ (365 ppm during 1990-2005). Fig. 

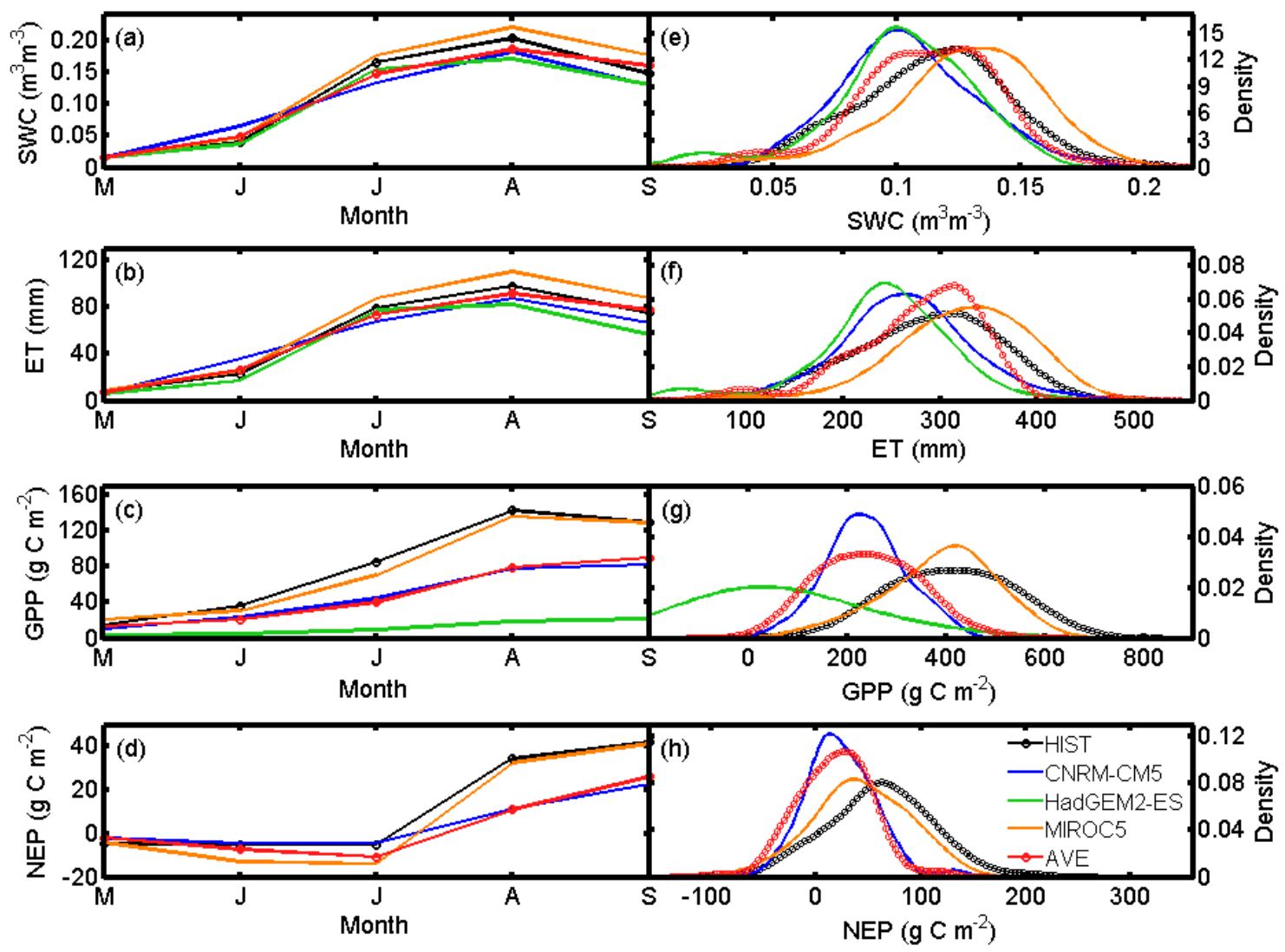

Figure 7. Comparison of water, energy and carbon dynamics for historical (1990-2005) and climate change experiments (2030-2045) using representative realizations for HIST, CNRMCM5, HadGEM2-ES, MIROC5 and AVE. Monthly mean values and seasonal probability density

558 functions of (a, e) soil water content (SWC), (b, f) evapotranspiration (ET), (c, g) gross primary productivity (GPP) and (d, h) net ecosystem productivity (NEP) during summer (MJJAS). are obtained as averages over the 100 -yr periods, while the probability density functions show the full range of total summer season outcomes from each scenario and thus indicate interannual variability represented for historical and near-future conditions. The imposed air temperature and

568 precipitation changes resulted in substantial summertime variations in the water, energy and carbon dynamics among the climate change experiments. For instance, scenarios with summer 
570 precipitation lower than HIST (HadGEM2-ES and CNRM-CM5, Fig. 6d) exhibited decreases in

571 SWC (Fig. 7a,e) and ET (Fig. 7b,f), whereas scenarios with summer P at or above HIST (AVE

572 and MIROC5) showed SWC and ET that were similar to or higher than HIST.

573 The strong correspondence between summer ET and SWC across simulations $\left(\mathrm{R}^{2}>0.88\right.$,

$574 \mathrm{p}<0.05)$ is typical of seasonally-dry ecosystems (e.g. Scott et al., 2010; Vivoni et al., 2008).

575 Nevertheless, air temperature differences among the climate change experiments also influenced

576 ET through the sensitivity of plant physiological activity to warming. Specifically, stomatal

577 conductance $\left(\mathrm{g}_{\mathrm{s}}\right)$ in the simulations was reduced with rising TA for a constant $\mathrm{CO}_{2}$ value due to

578 increasing vapor pressure deficit and reductions on soil water content (Verduzco, 2016). As an

579 example, the HadGEM2-ES scenario with the highest TA (Fig. 6c) exhibited increased

580 evaporative demand, which causes complete vegetation failure leading to a reduction in ET due

581 to elimination of the transpiration component. This is consistent with field studies in semiarid

582 ecosystems reporting decreased stomatal conductance and carbon assimilation under warming-

583 induced stress (Hamerlynck \& Knapp, 1996; Hamerlynck et al., 2000; Ogle \& Reynolds, 2002;

584 Serrat-Capdevila et al., 2011).

Interestingly, differences among the climate change experiments were more pronounced when comparing carbon dynamics through the monthly evolution and summer total GPP (Fig.

587 7c,g) and NEP (Fig. 7d,h). This can be explained through the compensating effects of rising TA 588 and changing $\mathrm{P}$ on plant productivity and ecosystem respiration. For instance, MIROC5 and 589 AVE exhibit similar values of TA that were both larger than HIST (Fig. 6c), but there is a larger 590 summer P in MIROC5 as compared to both AVE and HIST (which have similar totals, Fig. 6d).

591 While rising TA increases evaporative demand, higher P reduces soil moisture stress. The net 592 result is an increase in GPP and NEP in MIROC5 relative to AVE, whereas MIROC5 and HIST 
593 are fairly close with respect to summer season carbon fluxes. This suggests that higher summer P

594 has the capacity to compensate for increased summer TA (MIROC5 vs. HIST), while

595 maintaining similar precipitation under rising temperature leads to a lower GPP and NEP (AVE

596 vs. HIST). This latter case is consistent with experimental studies where increased temperatures

597 have been shown to unfavorably affect productivity under constant precipitation treatments (e.g.

598 Epstein et al., 1997; Mowll et al., 2015; Wu et al., 2011). Moreover, large increases in TA along with decreases in P, like the HadGEM2-ES scenario, significantly decrease GPP in the

600

601

602

603

604

605

606

607

608

609

610

611

612

613

614

615

subtropical shrubland such that there is a collapse in the simulated plant activity. As a result, increased summertime air temperatures and reduced precipitation could cause large impacts on vegetation productivity that would require further plant adaptations or variations in community composition, as suggested in prior work (Dieleman et al., 2015; Goyal, 2004; Lavee et al., 1998; Moritz \& Agudo, 2013; Ponce Campos et al., 2013; Schwinning \& Ehleringer, 2001).

A closer inspection of the summer carbon fluxes in Fig. 8 reveals substantial variations between pre-monsoon (MJ) and monsoon (JAS) periods in the scenarios (HadGEM2-ES is omitted as GPP approached zero after 35 years of simulation) as well as the relative importance of heterotrophic $\left(\mathrm{R}_{\mathrm{h}}\right)$ and ecosystem respiration $\left(\mathrm{R}_{\mathrm{ECO}}\right)$ on net ecosystem productivity. For all scenarios, pre-monsoon magnitudes of $\mathrm{R}_{\mathrm{h}}$ and $\mathrm{R}_{\mathrm{ECO}}$ were smaller than respiration fluxes during the monsoon, consistent with the drier soil conditions and lower microbial biomass (Fig. 8a, b), as presented in other sites in the NAM region (Barron-Gafford et al., 2012). Furthermore, $\mathrm{R}_{\mathrm{h}}$ is a larger fraction of $\mathrm{R}_{\mathrm{ECO}}$ for the pre-monsoon period $\left(\mathrm{R}_{\mathrm{h}} / \mathrm{R}_{\mathrm{ECO}}=0.53,0.52,0.51\right.$ and 0.55 for HIST, CNRM-CM5, MIROC5 and AVE) as compared to monsoon conditions $\left(\mathrm{R}_{\mathrm{h}} / \mathrm{R}_{\mathrm{ECO}}=0.32\right.$, $0.31,0.33$ and 0.34 ), indicating that $\mathrm{R}_{\mathrm{a}}$ increases in importance during the summer. Variations in monsoon values of respiration fluxes across the scenarios follow patterns in gross primary

This article is protected by copyright. All rights reserved. 
616 productivity (Fig. 7g), as shown in prior studies (Gómez-Casanovas et al., 2012; Stoy et al.,

617 2009). For example, $R_{h}$ was correlated well with $\operatorname{GPP}\left(R^{2}>0.60, p<0.05\right)$ such that scenarios

618 with a higher GPP (HIST and MIROC5) exhibit higher $\mathrm{R}_{\mathrm{h}}$ due to the increased availability of

619 litterfall for decomposition (Fig. 8b,c). In contrast, pre-monsoon periods showed sensitivity to

620 both GPP and SWC such that MIROC5 with a higher P had substantially larger $\mathrm{R}_{\mathrm{h}}$ than those

621 scenarios with similar TA but lower P. This is consistent with other studies indicating that

622 productivity enhancements via water availability are more critical controls on respiration than air

623 temperature changes in semiarid ecosystems (Janssens et al., 2001; Reichstein et al., 2003). Pre-

624 monsoon conditions also had substantially lower GPP and NEP as compared to the monsoon

625 period (Fig. 8c,d), with more negative values of NEP indicating the relative importance of $\mathrm{R}_{\mathrm{ECO}}$

626 as compared to GPP prior to the growing season. Furthermore, higher precipitation and rising air

627 temperatures (MIROC5) promote a more substantial $\mathrm{R}_{\mathrm{h}}$ that reduce NEP, whereas a lower $\mathrm{P}$ and

628 higher TA (CNRM-CM5 and AVE) resulted in NEP closer to zero. As result, subtropical

629 shrublands could become a larger net carbon source during pre-monsoon periods when warming

630 is coupled with increased precipitation.

631

632

633

634

635

636

637

638

639

\section{4. $\mathrm{CO}_{2}$ fertilization effects on simulated water, energy and carbon dynamics}

Superimposed effects of meteorological changes and increased atmospheric $\mathrm{CO}_{2}$ concentrations (482 ppm over the 2030-2045 period) were assessed using a second set of simulations for each model scenario (CNRM-CM5, HadGEM2-ES, MIROC5 and AVE). Fig. 9 presents the modeling outcomes for the climate change experiments (with and without $\mathrm{CO}_{2}$ fertilization) relative to the HIST (1990-2005) simulation and the summer (MJJAS) averaged observations (OBS, 2008-2012). Differences between HIST and OBS were only due to the sampling of different time periods since simulations during 2008-2012 were consistent with OBS

This article is protected by copyright. All rights reserved. 
640 (Table 4). For the higher $\mathrm{CO}_{2}$ scenarios, both GPP $\left(+172.1,188.5\right.$ and $210.5 \mathrm{~g} \mathrm{C} \mathrm{m}^{-2}$ for CNRM-

641 CM5, MIROC5 and AVE, respectively) and $\mathrm{R}_{\mathrm{ECO}}\left(+146.9,147.0\right.$ and $\left.153.7 \mathrm{~g} \mathrm{C} \mathrm{m}^{-2}\right)$ show

642 increases when compared to the $\mathrm{CO}_{2}$ of 365 ppm case (Fig. 9a, b). Thus, for the same set of

643 imposed meteorological changes, increased atmospheric $\mathrm{CO}_{2}$ enhances GPP, as seen in field and

644 remote sensing studies (Ainsworth \& Long, 2005; Donohue et al., 2013; Morgan et al., 2004;

645 Wang et al., 2012), and that is consistent with higher observed ecosystem respiration. Larger

646 enhancements in GPP and $\mathrm{R}_{\mathrm{ECO}}$ were noted for scenarios with more precipitation during the

647 summer (MIROC5 vs. CNRM-CM5). However, the increase in GPP due to $\mathrm{CO}_{2}$ fertilization

648 exceeds that of $\mathrm{R}_{\mathrm{ECO}}$ due to a reduction of the autotrophic respiration per unit leaf area (e.g.

649 Drake et al., 1997). As a result, NEP from the $\mathrm{CO}_{2}$ fertilization experiments increased in terms of 650 the median value and the range of values in all scenarios relative to simulations without a rising

$651 \mathrm{CO}_{2}$ (Fig. 9c). Thus, $\mathrm{CO}_{2}$ fertilization offsets the meteorological impacts on NEP in the near-

652 future (2030-2045) at the expense of an increase summer interannual variability. The positive

653 effects of fertilization on the median NEP varied across the scenarios $(+34.6,33.2$ and $33.9 \mathrm{~g} \mathrm{C}$

$654 \mathrm{~m}^{-2}$ ) with a higher increase for AVE with the largest increase in WUE. In addition, the $\mathrm{CO}_{2}$

655 fertilization altered NEP at the subtropical shrubland under the HadGEM2-ES scenario

656 permitting ecosystem resilience and a positive carbon balance.

657 The role of precipitation changes on enhancing NEP was further explored by comparing

658 SWC for the two sets of $\mathrm{CO}_{2}$ experiments. As expected, higher GPP for scenarios with $\mathrm{CO}_{2}$

659 fertilization was linked to a dramatic increase in LAI (+72\%, 45\% and 73\% for CNRM-CM5,

660 MIROC5 and AVE, respectively) relative to the cases with $\mathrm{CO}_{2}$ at $365 \mathrm{ppm}$, which resulted in a

661 higher summertime ET (+18, 13 and $21 \mathrm{~mm})$. While the higher ET under $\mathrm{CO}_{2}$ fertilization would 

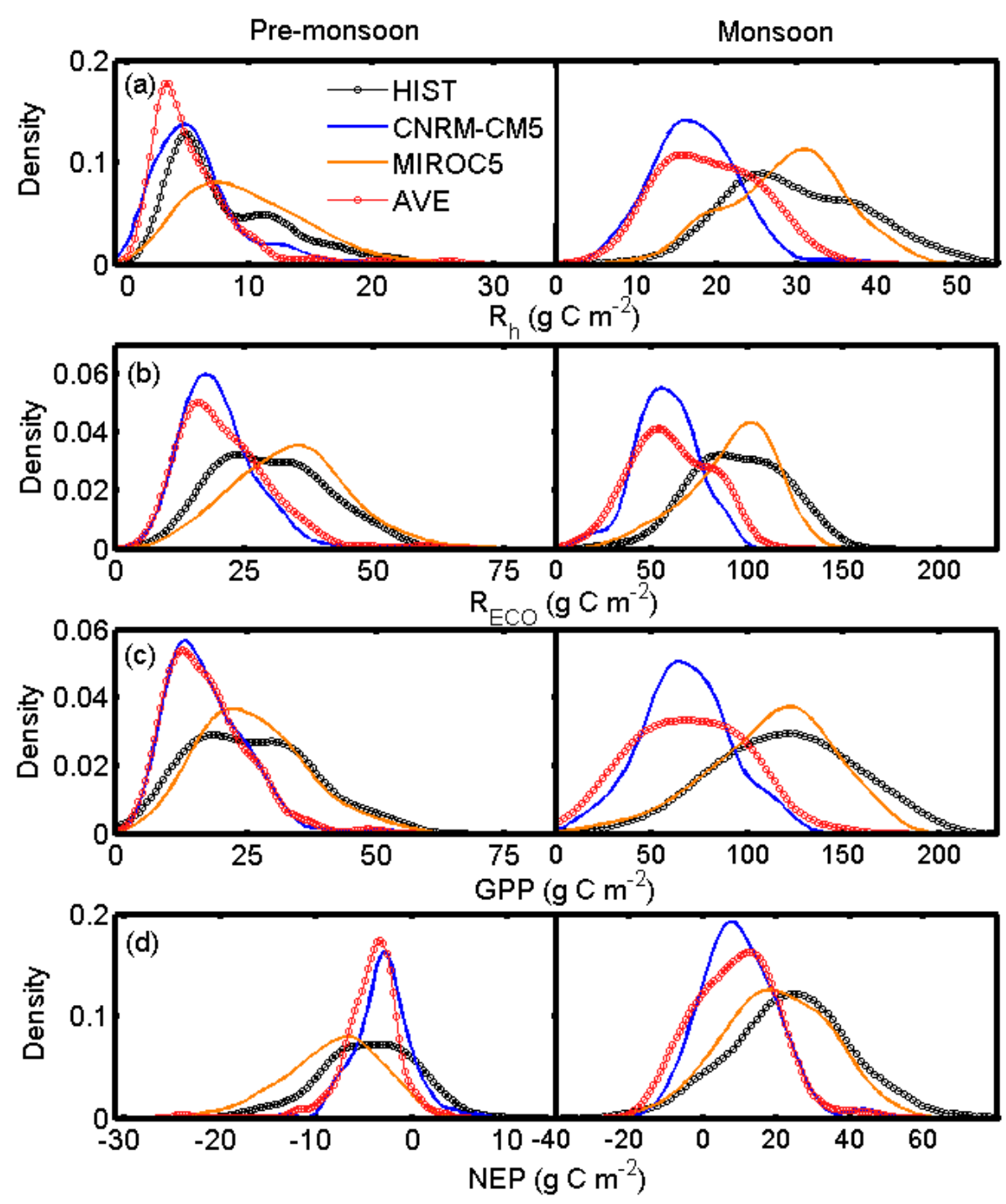

663

664

665

666

667

668

669

670

671

672

673

Figure 8. Comparison of carbon dynamics for historical (1990-2005) and climate change experiments (2030-2045) using representative realizations for HIST, CNRM-CM5, MIROC5 and AVE for pre-monsoon (MJ) and monsoon (JAS) periods. Probability density functions of (a) heterotrophic respiration $\left(\mathrm{R}_{\mathrm{h}}\right)$, (b) ecosystem respiration $\left(\mathrm{R}_{\mathrm{ECO}}\right)$, (c) gross primary productivity (GPP) and (d) net ecosystem productivity (NEP) totals during each period.

be expected to deplete soil water, we found no appreciable changes in SWC of the top $10 \mathrm{~cm}$ of soil $\left(+0.0013,0.0007\right.$ and $\left.0.0019 \mathrm{~m}^{3} / \mathrm{m}^{3}\right)$, even for cases where summertime precipitation decreased or remained similar (CNRM-CM5 and AVE). These results are consistent with Fatichi et al. (2016a) who showed that increased WUE supports a higher LAI through soil water savings but leads to a more rapid consumption of SWC due to the increased vegetation. The effects of 

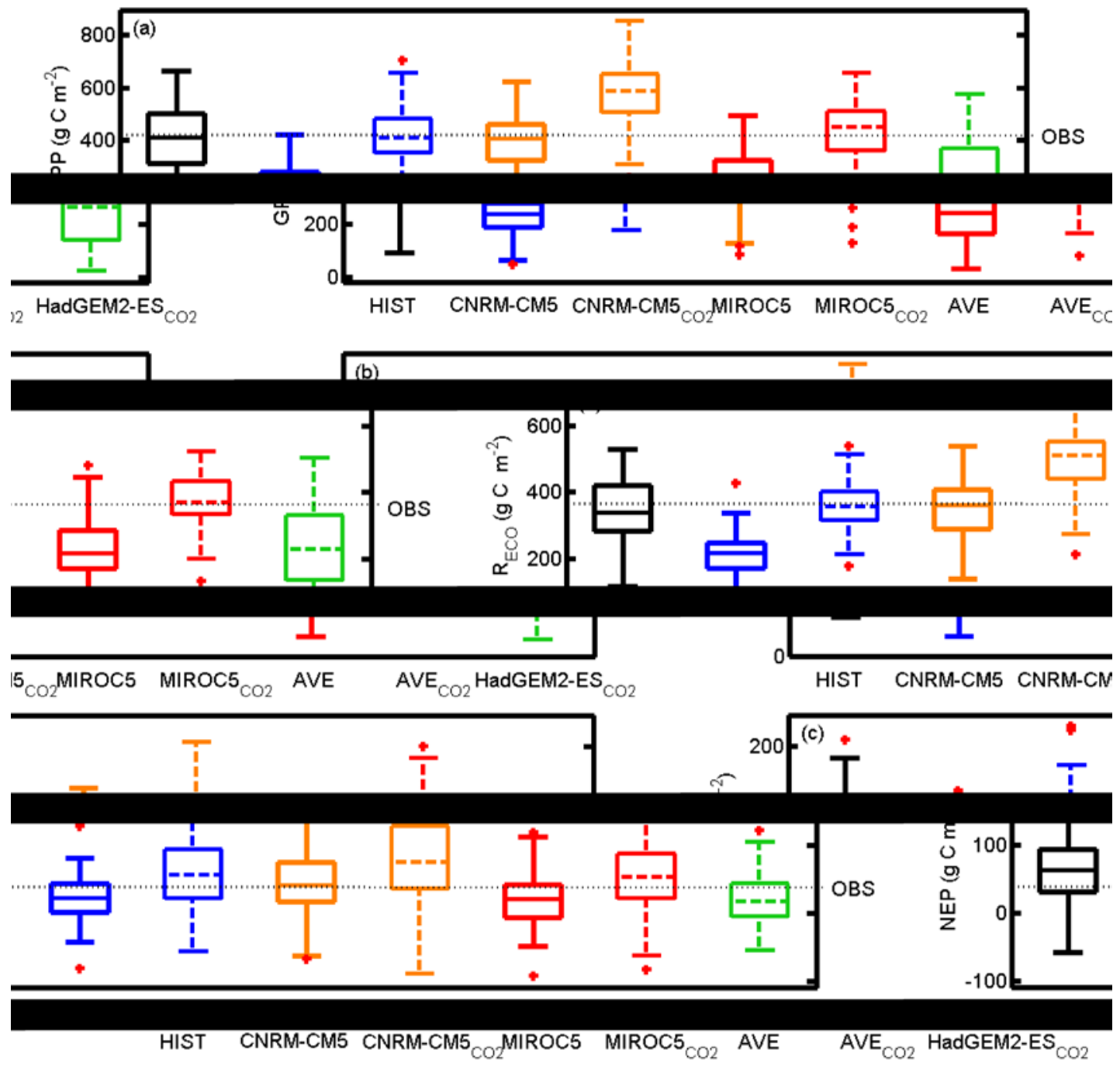

674

675

676

677

678

679

680

681

682

683

684

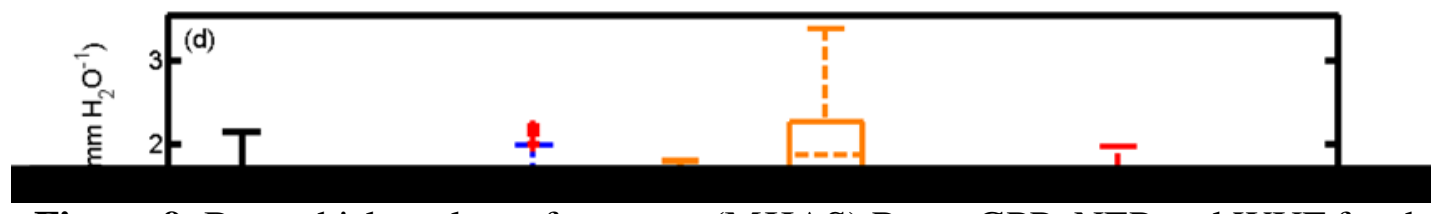

Figure 9. Box-whisker plots of summer (MJJAS) $\mathrm{R}_{\mathrm{ECO}}$, GPP, NEP and WUE for the climate change experiments under meteorological changes and superimposed $\mathrm{CO}_{2}$ fertilization (labeled with subscript $\mathrm{CO}_{2}$ ) using representative realizations for HIST, CNRM-CM5,

HadGEM2-ES, MIROC5 and AVE. Dashed horizontal line in each subplots represents summer averages from observations (OBS, 2008-2012).

increased $\mathrm{CO}_{2}$ on gains in NEP despite a similar SWC when compared to scenarios without

fertilization is attributed to ecosystem alterations in water use efficiency (WUE = GPP/ET, Fig.

9d), which increased substantially $(+68 \%, 42 \%$ and $69 \%)$ at the expense of higher summertime

interannual variability. Thus, a secondary effect of $\mathrm{CO}_{2}$ fertilization is to allow more productive

This article is protected by copyright. All rights reserved. 
summers (i.e. higher NEP), when precipitation is not limiting, through higher WUE. As a result, $\mathrm{CO}_{2}$ fertilization leads to a more efficient but variable ecosystem in terms of biomass production per amount of water consumed in most of the scenarios. Prior investigations have identified similar $\mathrm{CO}_{2}$ fertilization effects on WUE, including through experimental studies of semiarid plants (e.g. Leakey et al., 2009, Morgan et al., 2011, Xu et al., 2014) and analyses of remotelysensed data in drylands (e.g. Donohue et al., 2013, Lu et al., 2016). Nevertheless, it has been uncommon to measure WUE directly in semiarid regions with strong vegetation dynamics. As such, there is a need to conduct additional observational analyses in seasonally-dry ecosystems to compare with our model-based estimates of the $\mathrm{CO}_{2}$ fertilization effect on WUE ( $+40 \%$ to $70 \%$ ), as have been performed in temperate forests (Kauwe et al., 2013). In our study, the increase in WUE was greater in the warmest scenario (HadGEM2-ES) since elevated $\mathrm{CO}_{2}$ allows plants to decrease stomatal conductance, while maintaining photosynthetic rates (Blumenthal et al., 2013), which resulted in positive NEP under $\mathrm{CO}_{2}$ fertilization. Similar effects have been observed under experimental $\mathrm{CO}_{2}$ fertilization (e.g. Cernusak et al., 2013; Conley et al., 2001) and more recently as a trend due to rising $\mathrm{CO}_{2}$ concentrations (e.g. Maseyk et al., 2011; Lu et al., 2016).

\section{Summary and conclusions}

In this work, we combined ecohydrological and soil carbon models to simulate water, energy and carbon dynamics in a seasonally-dry, semiarid ecosystem of northwestern México across temporal resolutions ranging from hourly to interannual variability. Compared to a set of field and remotely-sensed observations, the tRIBS-VEGGIE and SCM simulations accurately captured the seasonality of vegetation activity and carbon fluxes of subtropical shrublands (Méndez-Barroso et al., 2014; Villarreal et al., 2016; Vivoni et al., 2010a). In addition, the simulations represent the main features of net primary productivity in the region, specifically a 
709 large respiration pulse early in the summer followed by a gradual switch to carbon fixation

710 during the growing season (Huxman et al., 2004b; Verduzco et al., 2015; Yépez et al., 2007).

711 This indicated that the simulation of soil (heterotrophic) respiration is an essential component for 712 reproducing the observed carbon dynamics in this type of ecosystem. Furthermore, simulated $R_{h}$

713 was highly sensitive to timing of the first storms during the NAM that increase soil water content 714 and to the amount of labile substrate derived from litterfall from the previous summer. Insights 715 gained from the ecohydrological and soil carbon model application could potentially serve to 716 improve terrestrial biosphere models (e.g. Huntzinger et al., 2012) that have been shown to 717 misrepresent carbon dynamics in semiarid shrublands. Nevertheless, the use of the combined 718 models within this ecosystem could be improved by adding a plant functional type, such as 719 winter annuals (Werk et al., 1983) or evergreen shrubs (Biederman et al., 2018), that is active 720 from fall to spring. In this manner, the physiological activity during winters would enhance the 721 representation of vegetation dynamics and impact the generation and decomposition of litterfall, 722 thus affecting the respiratory efflux at the start of the following monsoon. This is consistent with 723 Verduzco et al. (2015) and Zhang et al. (2014) who suggested the net carbon balance depends on 724 the relative strength of the heterotrophic carbon release versus the primary productivity occurring 725 later in the growing season. Overall, both the observed record and simulations over the studied 726 (2008-2012) and historical (1990-2005) periods showed that the subtropical shrubland was 727 generally a net carbon sink (positive NEP) over both growing season and annual time scales. Subsequently, we conducted a comparison of historical (1990-2005) and near-future 729 (2030-2045) climate change scenarios obtained from the stochastic downscaling of three GCMs 730 (Fatichi et al., 2011, 2013) tailored for input to the tRIBS-VEGGIE and SCM models. Increased 731 near-future air temperatures reduced net ecosystem productivity, though a compensation effect 
732 was identified for some of GCMs (e.g., MIROC5) exhibiting higher summer precipitation as

733 compared to the historical scenario (HIST). This was attributed to higher plant stress under

734 warmer temperatures and lower precipitation, which limited GPP. Since $\mathrm{R}_{\mathrm{ECO}}$ was reduced to a

735 lesser degree than GPP, due to warmer temperatures and short-term substrate availability, a

736 lower NEP resulted in all scenarios, with compensation occurring when atmospheric $\mathrm{CO}_{2}$

737 concentration was increased. When GCM projections of summer precipitation were substantially

738 lower (HadGEM2-ES), a collapse of the simulated plant activity was observed (i.e. GPP

739 approaching zero). It should be noted, however, that tRIBS-VEGGIE simulations do not

740 currently account for plant thermal acclimation that can prevent 'diebacks' due to high

741 temperatures (Hamerlynck et al., 2000; Salvucci \& Crafts-Brandner, 2004) or for plant mortality

742 processes induced by cavitation (Fatichi et al., 2016b; Plaut et al., 2012), and thus the collapse of

743 plant activity under the HadGEM2-ES scenario is subject to considerable uncertainty.

744 Our main finding was that reductions in NEP under near-future meteorological changes

745 were significantly offset under the $\mathrm{CO}_{2}$ fertilization experiments for all considered GCMs. This

746 was mainly attributed to an increase in WUE under elevated $\mathrm{CO}_{2}$ concentrations via an indirect

747 effect on SWC as identified in other water-limited ecosystems (Fatichi et al., 2016b; Lu et al.,

748 2016). As a result of higher soil water content, the effects of warming-induced stress can be

749 offset, leading to increases in NEP in the near-future for all GCMs relative to the historical

750 period. Increases in WUE under $\mathrm{CO}_{2}$ fertilization help to explain how seasonally-dry ecosystems

751 can recover as a net carbon sink with a strength similar to the historical conditions under the

752 superimposed climate change effects. For the scenario with higher summer precipitation

753 (MIROC5), near-future NEP is larger than HIST, whereas for the case with the highest summer

754 temperature (HadGEM2-ES), $\mathrm{CO}_{2}$ fertilization prevents the collapse of the simulated plant

This article is protected by copyright. All rights reserved. 
755 activity. Nevertheless, these projected changes are also subject to uncertainty since

756 photosynthetic acclimation to elevated $\mathrm{CO}_{2}$ (Newingham et al., 2013; Mueller et al., 2016; Sage

757 et al., 1989) is not currently considered.

758 Given the important role of semiarid regions in the terrestrial carbon budget (Ahlström et 759 al., 2015; Poulter et al., 2014), the effects of meteorological changes and $\mathrm{CO}_{2}$ fertilization on 760 carbon dynamics in seasonally-dry ecosystems could have regional to global consequences.

761 Under warming conditions, lower precipitation and increased atmospheric $\mathrm{CO}_{2}$, our study 762 suggests that semiarid ecosystems under the influence of the North American monsoon would 763 maintain a similar to actual net carbon balance by mid $21^{\text {st }}$ century. The offsetting of impacts 764 from meteorological changes in temperature and precipitation and those arising from $\mathrm{CO}_{2}$ 765 fertilization is an outcome of opposing controls on soil and plant-mediated carbon dynamics. 766 However, changes in the timing, intensity and distribution of precipitation during the growing 767 season (e.g. Cook \& Seager, 2013; Geil et al., 2013), in particular an increase in monsoon 768 rainfall (e.g. Hawkins et al., 2015; Robles-Morua et al., 2015), could lead to ecosystems acting as 769 larger net carbon sinks, due to an increase in water use efficiency under higher $\mathrm{CO}_{2}$ 770 concentrations, with implications on the global carbon budget. This outcome is consistent with 771 observed biomass trends indicating more efficient productivity in semiarid ecosystems (Donahue 772 et al., 2013), including those in the NAM region (Forzieri et al., 2014). While additional research 773 is necessary to confirm the findings of this study and their implications for terrestrial biosphere 774 models used to capture feedbacks to the climate system (Huntzinger et al., 2012), the combined 775 use of dynamic ecosystem level measurements and numerical modeling is a promising avenue 776 for deciphering the net effect of climate change on the water, energy and carbon dynamics of 777 seasonally-dry, semiarid ecosystems. 
779 Acknowledgments

We thank the Consejo Nacional de Ciencia y Tecnología (CONACYT) in México for the 781 graduate fellowship to V.S.V. (231560) and T.T. (232184). This research project was supported 782 by CB-2013-01: 221014 to E.A.Y. and a US Fulbright and CONACYT Visiting Fellowships to 783 E.R.V. We also thank the World Climate Research Programme's Working Group on Coupled 784 Modelling, for producing and making available the climate change model output. We thank two 785 reviewers for excellent comments that helped to improve an earlier version of the manuscript.

786 Data access is available through Zenodo at http://doi.org/10.5281/zenodo.1116422 and the model 787 code and outputs utilized in this study can be requested from the corresponding author. 


\section{References}

Ahlström, A., Raupach, M. R., Schurgers, G., Smith, B., Arneth, A., Jung, M., ... \& Kato, E. (2015). The dominant role of semi-arid ecosystems in the trend and variability of the land CO2 sink. Science, 348(6237), 895-899. https://doi.org/ 10.1126/science.aaa1668

Ainsworth, E. A., \& Long, S. P. (2005). What have we learned from 15 years of free-air CO2 enrichment (FACE)? A meta-analytic review of the responses of photosynthesis, canopy properties and plant production to rising CO2. New Phytologist, 165(2), 351-372. https://doi.org/10.1111/j.1469-8137.2004.01224.x.

Allard, V., Ourcival J.M., Rambal S., Joffre R., Rocheteau A. (2008). Seasonal and annual variation of carbon exchange in an evergreen Mediterranean forest in southern France. Global Change Biology, 14(4), 714-725. https://doi.org/10.1111/j.13652486.2008.01539.x

Amthor, J.S. (1984) The role of maintenance respiration in plant growth. Plant, Cell \& Environment, 7(8), 561-569. https://dor.org/10.1111/1365-3040.ep11591833

Anderson, C. A., \& Vivoni, E. R. (2016) Impact of land surface states within the flux footprint on daytime land-atmosphere coupling in two semiarid ecosystems of the Southwestern US. Water Resources Research, 52(6), 4785-4800. https://doi.org/10.1002/2015WR018016

Arnone Iii, J. A., Verburg, P. S., Johnson, D. W., Larsen, J. D., Jasoni, R. L., Lucchesi, A. J., ... \& Buck, P. E. (2008) Prolonged suppression of ecosystem carbon dioxide uptake after an anomalously warm year. Nature, 455(7211), 383-386. http://doi.org/10.1038/nature07296

Aubinet, M., Grelle, A., Ibrom, A., Rannik, Ü., Moncrieff, J., Foken, T., ... \& Clement, R. (2000) Estimates of the annual net carbon and water exchange of forests: The EUROFLUX methodology. Advances in Ecological Research, 30, 113-175. https://doi.org/10.1016/S0065-2504(08)60018-5

Babst, F., Bouriaud, O., Papale, D., Gielen, B., Janssens, I. A., Nikinmaa, E., ... \& Grünwald, T. (2014) Above-ground woody carbon sequestration measured from tree rings is coherent with net ecosystem productivity at five eddy-covariance sites. New Phytologist, 201(4), 1289-1303. https://doi.org/10.1111/nph.12589

Baldocchi, D., Falge, E., Gu, L., Olson, R., Hollinger, D., Running, S., ... \& Fuentes, J. (2001). FLUXNET: A new tool to study the temporal and spatial variability of ecosystem-scale carbon dioxide, water vapor, and energy flux densities. Bulletin of the American Meteorological Society, 82(11), 2415-2434. https://doi.org/10.1175/15200477(2001)082<2415:FANTTS>2.3.CO;2

Baldocchi, D. D. (2003). Assessing the eddy covariance technique for evaluating carbon dioxide exchange rates of ecosystems: past, present and future. Global Change biology, 9(4), 479-492. https://doi.org/ 10.1046/j.1365-2486.2003.00629.x

Baldocchi, D.D. (2008). 'Breathing' of the terrestrial biosphere: lessons learned from a global network of carbon dioxide flux measurement systems. Australian Journal of Botany, 56(1), 1-26. https://doi.org/10.1071/BT07151

Barr, A. G., Richardson, A. D., Hollinger, D. Y., Papale, D., Arain, M. A., Black, T. A., ... \& Law, B. E. (2013). Use of change-point detection for friction-velocity threshold evaluation in eddy-covariance studies. Agricultural and Forest Meteorology, 171, 31-45. https://doi.org/10.1016/j.agrformet.2012.11.023 
Barron-Gafford, G. A., Scott, R. L., Jenerette, G. D., Hamerlynck, E. P., \& Huxman, T. E. (2012). Temperature and precipitation controls over leaf-and ecosystem-level CO2 flux along a woody plant encroachment gradient. Global Change Biology, 18(4), 1389-1400. 10.1111/j.1365-2486.2011.02599.x

Biederman, J. A., Scott, R. L., Goulden, M. L., Vargas, R., Litvak, M. E., Kolb, T. E., ... \& Garatuza-Payan, J. (2016). Terrestrial carbon balance in a drier world: the effects of water availability in southwestern North America. Global Change Biology, 22(5), 1867-1879. https://doi.org/10.1111/gcb.13222

Biederman, J. A., Scott, R. L., Bell, T., Bowling, D., Dore, S., Garatuza-Payan, J., Kolb, T., Kirishnan, P., Krofcheck, D., Litvak, M., Maurer, G., Meyers, T., Oechel, W., Papuga, S., Ponce Campos, G. E., Rodriguez, J., Smith, W., Vargas, E., Watts, C., Yepez, E., \& Goulden, M. (2017). CO2 exchange and evapotranspiration across dryland ecosystems of southwestern North America. Global Change Biology, 23, 4204-4221. https://doi.org/10.1111/gcb.13686.

Biederman, J. A., Scott, R. L., Arnone, J., Jasoni, R. L., Litvak, M. E., Moreo, M. T., Papuga, S. A., Ponce-Campos, G. E., Schreiner-McGraw, A. P., \& Vivoni, E.R. (2018). Shrubland carbon sink depends upon winter water availability in the warm deserts of North America. Agricultural and Forest Meteorology, 249, 407-419. https://doi.org/10.1016/j.agrformet.2017.11.005

Blumenthal, D. M., Resco, V., Morgan, J. A., Williams, D. G., LeCain, D. R., Hardy, E. M., ... \& Bladyka, E. (2013). Invasive forb benefits from water savings by native plants and carbon fertilization under elevated CO2 and warming. New Phytologist, 200(4), 1156-1165. https://doi.org/10.1111/nph.12459

Bolker, B. M., Pacala, S. W., \& Parton, W. J. (1998). Linear analysis of soil decomposition: insights from the century model. Ecological Applications, 8(2), 425-439. https://doi.org/10.1890/1051-0761(1998)008[0425:LAOSDI]2.0.CO;2

Bolton, H., Smith, J. L., \& Link, S. O. (1993). Soil microbial biomass and activity of a disturbed and undisturbed shrub-steppe ecosystem. Soil Biology and Biochemistry, 25(5), 545-552. https://doi.org/10.1016/0038-0717(93)90192-E

Brown, DE (1994) Biotic Communities: Southwestern United States and Northwestern México. University of Utah Press, Salt Lake City, UT.

Búrquez, A., Martínez-Yrízar, A., \& Núñez, S. (1999). Sonoran Desert productivity and the effect of trap size on litterfall estimates in dryland vegetation. Journal of Arid Environments, 43(4), 459-465. https://doi.org/10.1006/jare.1999.0547

Cable, J. M., Ogle, K., Williams, D. G., Weltzin, J. F., \& Huxman, T. E. (2008). Soil texture drives responses of soil respiration to precipitation pulses in the Sonoran Desert: implications for climate change. Ecosystems, 11(6), 961-979. https://doi.org/10.1007/s10021-008-9172-X

Carbone, M. S., Still, C. J., Ambrose, A. R., Dawson, T. E., Williams, A. P., Boot, C. M., ... \& Schimel, J. P. (2011). Seasonal and episodic moisture controls on plant and microbial contributions to soil respiration. Oecologia, 167(1), 265-278. https://doi.org/10.1007/s00442-011-1975-3

Carbone, M. S., Richardson, A. D., Chen, M., Davidson, E. A., Hughes, H., Savage, K. E., \& Hollinger, D. Y. (2016). Constrained partitioning of autotrophic and heterotrophic respiration reduces model uncertainties of forest ecosystem carbon fluxes but not 
stocks. Journal of Geophysical Research: Biogeosciences, 121(9), 2476-2492. https://doi.org/10.1002/2016JG003386

Cardoso, J. A. F., Lima, A. M. N., Cunha, T. J. F., Rodrigues, M. S., Hernani, L. C., Amaral, A. J. D., \& Oliveira Neto, M. B. D. (2015). Organic matter fractions in a Quartzipsamment under cultivation of irrigated Mmango in the Lower São Francisco valley region, Brazil. Revista Brasileira de Ciência do Solo, 39(4), 1068-1078. https://dx.doi.org/10.1590/01000683rbcs20140498

Castro, C. L., Chang, H. I., Dominguez, F., Carrillo, C., Schemm, J. K., \& Henry Juang, H. M. (2012). Can a regional climate model improve the ability to forecast the North American monsoon?. Journal of Climate, 25(23), 8212-8237. https://doi.org/10.1175/JCLI-D-1100441.1

Cerezo-Mota, R., Allen, M., \& Jones, R. (2011). Mechanisms controlling precipitation in the northern portion of the North American monsoon. Journal of Climate, 24(11), 27712783. https://doi.org/10.1175/2011JCLI3846.1

Cernusak, L. A., Winter, K., Dalling, J. W., Holtum, J. A., Jaramillo, C., Körner, C., ... \& Wright, S. J. (2013). Tropical forest responses to increasing atmospheric CO2: current knowledge and opportunities for future research. Functional Plant Biology, 40(6), 531551. https://doi.org/10.1071/FP12309

Collins, S. L., Belnap, J., Grimm, N. B., Rudgers, J. A., Dahm, C. N., D'odorico, P., ... \& Sinsabaugh, R. L. (2014). A multiscale, hierarchical model of pulse dynamics in arid-land ecosystems. Annual Review of Ecology, Evolution, and Systematics, 45, 397-419. https://doi.org/10.1146/annurev-ecolsys-120213-091650

Conant, R. T., Dalla-Betta, P., Klopatek, C. C., \& Klopatek, J. M. (2004). Controls on soil respiration in semiarid soils. Soil Biology and Biochemistry, 36(6), 945-951. https://doi.org/10.1016/j.soilbio.2004.02.013

Conley, M. M., Kimball, B. A., Brooks, T. J., Pinter, P. J., Hunsaker, D. J., Wall, G. W., ... \& Leavitt, S. W. (2001). CO2 enrichment increases water-use efficiency in sorghum. New Phytologist, 151(2), 407-412. https://doi.org/10.1046/j.1469-8137.2001.00184.x

Cook, B. I., \& Seager, R. (2013). The response of the North American Monsoon to increased greenhouse gas forcing. Journal of Geophysical Research: Atmospheres, 118(4), 16901699. https://doi.org/10.1002/jgrd.50111

Cheng, M., Xue, Z., Xiang, Y., Darboux, F., \& An, S. (2015). Soil organic carbon sequestration in relation to revegetation on the Loess Plateau, China. Plant and Soil, 397(1-2), 31-42. https://doi.org/10.1007/s11104-015-2486-5

Davidson, E. A., Janssens, I. A., \& Luo, Y. (2006). On the variability of respiration in terrestrial ecosystems: moving beyond Q10. Global Change Biology, 12(2), 154-164. https://doi.org/10.1111/j.1365-2486.2005.01065.x

Desai, A. R., Richardson, A. D., Moffat, A. M., Kattge, J., Hollinger, D. Y., Barr, A., ... \& Stauch, V. J. (2008). Cross-site evaluation of eddy covariance GPP and RE decomposition techniques. Agricultural and Forest Meteorology, 148(6), 821-838. https://doi.org/10.1016/j.agrformet.2007.11.012

Dieleman, C. M., Branfireun, B. A., McLaughlin, J. W., \& Lindo, Z. (2015). Climate change drives a shift in peatland ecosystem plant community: implications for ecosystem function and stability. Global Change Biology, 21(1), 388-395. https://doi.org/10.1111/gcb.12643 
Donohue, R. J., Roderick, M. L., McVicar, T. R., \& Farquhar, G. D. (2013). Impact of CO2 fertilization on maximum foliage cover across the globe's warm, arid environments. Geophysical Research Letters, 40(12), 3031-3035. https://doi.org/10.1002/grl.50563

Douglas, M. W., Maddox, R. A., Howard, K., \& Reyes, S. (1993). The mexican monsoon. Journal of Climate, 6(8), 1665-1677. https://doi.org/10.1175/15200442(1993)006<1665:TMM>2.0.CO;2

Drake, B. G., Gonzàlez-Meler, M. A., \& Long, S. P. (1997). More efficient plants: a consequence of rising atmospheric CO2?. Annual Reviews of Plant Biology, 48(1), 609639. https://doi.org/10.1146/annurev.arplant.48.1.609

Drake, J. E., Aspinwall, M. J., Pfautsch, S., Rymer, P. D., Reich, P. B., Smith, R. A., ... \& Tjoelker, M. G. (2015). The capacity to cope with climate warming declines from temperate to tropical latitudes in two widely distributed Eucalyptus species. Global Change Biology, 21(1), 459-472. https://doi.org/10.1111/gcb.12729

Duan, Q. Y., Gupta, V. K., \& Sorooshian, S. (1993). Shuffled complex evolution approach for effective and efficient global minimization. Journal of Optimization Theory and Applications, 76, 501-521. https://doi.org/10.1007/BF00939380

Duarte, H. F., Dias, N. L., \& Maggiotto, S. R. (2006). Assessing daytime downward longwave radiation estimates for clear and cloudy skies in Southern Brazil. Agricultural and Forest Meteorology, 139(3), 171-181. https://doi.org/10.1016/j.agrformet.2006.06.008

Duursma, R. A., Barton, C. V. M., Lin, Y-S., Medlyn, B. E., Eamus, D., Tissue, D. T., Ellsworth, D. S., and McMurthie, R. E. (2014). The peaked response of transpiration rate to vapour pressure deficit in field conditions can be explained by the temperature optimum of photosynthesis. Agricultural and Forest Meteorology, 189-190: 2-10. https://doi.org/10.1016/j.agrformet.2013.12.007

Epstein, H. E., Lauenroth, W. K., \& Burke, I. C. (1997). Effects of temperature and soil texture on ANPP in the US Great Plains. Ecology, 78(8), 2628-2631. https://doi.org/10.1890/0012-9658(1997)078[2628:EOTAST]2.0.CO;2

Euskirchen, E. S., Edgar, C. W., Turetsky, M. R., Waldrop, M. P., \& Harden, J. W. (2014). Differential response of carbon fluxes to climate in three peatland ecosystems that vary in the presence and stability of permafrost. Journal of Geophysical Research: Biogeosciences, 119(8), 1576-1595. https://doi.org/10.1002/2014JG002683

Fan, J., Jones, S. B., Qi, L. B., Wang, Q. J., \& Huang, M. B. (2012). Effects of precipitation pulses on water and carbon dioxide fluxes in two semiarid ecosystems: measurement and modeling. Environmental Earth Sciences, 67(8), 2315-2324. https://doi.org/10.1007/s12665-012-1678-z.

Fatichi, S., Ivanov, V. Y., \& Caporali, E. (2013). Assessment of a stochastic downscaling methodology in generating an ensemble of hourly future climate time series. Climate Dynamics, 40(7-8), 1841-1861. https://doi.org/10.1007/s00382-012-1627-2

Fatichi, S., Ivanov, V. Y., \& Caporali, E. (2011). Simulation of future climate scenarios with a weather generator. Advances in Water Resources, 34(4), 448-467. https://doi.org/10.1016/j.advwatres.2010.12.013

Fatichi, S., Leuzinger, S., Paschalis, A., Langley, J. A., Barraclough, A. D., \& Hovenden, M. J. (2016). Partitioning direct and indirect effects reveals the response of water-limited ecosystems to elevated CO2. Proceedings of the National Academy of Sciences, 113(45), 12757-12762. https://doi: 10.1073/pnas.1605036113 
Fatichi, S., Pappas, C., \& Ivanov, V. Y. (2016b). Modeling plant-water interactions: an ecohydrological overview from the cell to the global scale. Wiley Interdisciplinary Reviews: Water, 3(3), 327-368. https://doi.org/10.1002/wat2.1125

Fensholt, R., Sandholt, I., \& Rasmussen, M. S. (2004). Evaluation of MODIS LAI, fAPAR and the relation between fAPAR and NDVI in a semi-arid environment using in situ measurements. Remote Sensing of Environment, 91(3), 490-507. https://doi.org/10.1016/j.rse.2004.04.009

Fisher, J. B., Huntzinger, D. N., Schwalm, C. R., \& Sitch, S. (2014). Modeling the terrestrial biosphere. Annual Reviews of Environment and Resources, 39, 91-123. https://doi.org/10.1146/annurev-environ-012913-093456

Flanagan, L. B., Wever, L. A., \& Carlson, P. J. (2002). Seasonal and interannual variation in carbon dioxide exchange and carbon balance in a northern temperate grassland. Global Change Biology, 8(7), 599-615. https://doi.org/10.1046/j.1365-2486.2002.00491.x

Flato, G., Marotzke, J., Abiodun, B., Braconnot, P., Chou, S. C., Collins, W. J., ... \& Forest, C. (2013). Evaluation of Climate Models. In: Climate Change 2013: The Physical Science Basis. Contribution of Working Group I to the Fifth Assessment Report of the Intergovernmental Panel on Climate Change. Climate Change 2013, 5, 741866.https://doi.org/10.1017/CBO9781107415324.020

Follett, R. F., Paul, E. A., \& Pruessner, E. G. (2007). Soil carbon dynamics during a long-term incubation study involving 13C and 14C measurements. Soil Science, 172(3), 189-208. https://doi.org/10.1097/ss.0b013e31803403de

Forzieri, G., Feyen, L., Cescatti, A., \& Vivoni, E. R. (2014). Spatial and temporal variations in ecosystem response to monsoon precipitation variability in southwestern North America. Journal of Geophysical Research: Biogeosciences, 119(10), 1999-2017. https://doi.org/10.1002/2014JG002710

Friedlingstein, P., Meinshausen, M., Arora, V. K., Jones, C. D., Anav, A., Liddicoat, S. K., \& Knutti, R. (2014). Uncertainties in CMIP5 climate projections due to carbon cycle feedbacks. Journal of Climate, 27(2), 511-526. https://doi.org/10.1175/JCLI-D-1200579.1

Geil, K. L., Serra, Y. L., \& Zeng, X. (2013). Assessment of CMIP5 model simulations of the North American monsoon system. Journal of Climate, 26(22), 8787-8801. https://doi.org/10.1175/JCLI-D-13-00044.1

Gherardi, L. A., \& Sala, O. E. (2015). Enhanced precipitation variability decreases grass-and increases shrub-productivity. Proceedings of the National Academy of Sciences, 112(41), 12735-12740. https://doi.org/ 10.1073/pnas.1506433112

Goberna, M., Pascual, J. A., Garcia, C., \& Sánchez, J. (2007). Do plant clumps constitute microbial hotspots in semiarid Mediterranean patchy landscapes?. Soil Biology and Biochemistry, 39(5), 1047-1054. https://doi.org/10.1016/j.soilbio.2006.11.015

Gomez-Casanovas, N., Matamala, R., Cook, D. R., \& Gonzalez-Meler, M. A. (2012). Net ecosystem exchange modifies the relationship between the autotrophic and heterotrophic components of soil respiration with abiotic factors in prairie grasslands. Global Change Biology, 18(8), 2532-2545. https://doi.org/10.1111/j.1365-2486.2012.02721.x

Goyal, R. K. (2004). Sensitivity of evapotranspiration to global warming: a case study of arid zone of Rajasthan (India). Agricultural Water Management, 69(1), 1-11. https://doi.org/10.1016/j.agwat.2004.03.014 
1014

1015

1016

1017

1018

1019

1020

1021

1022

1023

1024

1025

1026

1027

1028

1029

1030

1031

1032

1033

1034

1035

1036

1037

1038

1039

1040

1041

1042

1043

1044

1045

1046

1047

1048

1049

1050

1051

1052

1053

1054

1055

1056

1057

1058

1059

Grecu, M., \& Krajewski, W. F. (2000). A large-sample investigation of statistical procedures for radar-based short-term quantitative precipitation forecasting. Journal of Hydrology, 239(1), 69-84. https://doi.org/10.1016/S0022-1694(00)00360-7

Gu, L., Falge, E. M., Boden, T., Baldocchi, D. D., Black, T. A., Saleska, S. R., ... \& Xu, L. (2005). Objective threshold determination for nighttime eddy flux filtering. Agricultural and Forest Meteorology, 128(3), 179-197.

https://doi.org/10.1016/j.agrformet.2004.11.006

Gutmann, E., Pruitt, T., Clark, M. P., Brekke, L., Arnold, J. R., Raff, D. A., \& Rasmussen, R. M. (2014). An intercomparison of statistical downscaling methods used for water resource assessments in the United States. Water Resources Research, 50(9), 7167-7186. https://doi.org/10.1002/2014WR015559

Hamerlynck, E., \& Knapp, A. K. (1996). Photosynthetic and stomatal responses to high temperature and light in two oaks at the western limit of their range. Tree Physiology, 16(6), 557-565. https://doi.org/10.1093/treephys/16.6.557

Hamerlynck, E. P., Huxman, T. E., Loik, M. E., \& Smith, S. D. (2000). Effects of extreme high temperature, drought and elevated $\mathrm{CO} 2$ on photosynthesis of the Mojave Desert evergreen shrub, Larrea tridentata. Plant Ecology, 148(2), 183-193.

Harper, C. W., Blair, J. M., Fay, P. A., Knapp, A. K., \& Carlisle, J. D. (2005). Increased rainfall variability and reduced rainfall amount decreases soil $\mathrm{CO} 2$ flux in a grassland ecosystem. Global Change Biology, 11(2), 322-334. https://doi.org/10.1111/j.13652486.2005.00899.x

Hawkins, G. A., Vivoni, E. R., Robles-Morua, A., Mascaro, G., Rivera, E., \& Dominguez, F. (2015). A climate change projection for summer hydrologic conditions in a semiarid watershed of central Arizona. Journal of Arid Environments, 118, 9-20. https://doi.org/10.1016/j.jaridenv.2015.02.022

Heisler-White, J. L., Knapp, A. K., \& Kelly, E. F. (2008). Increasing precipitation event size increases aboveground net primary productivity in a semi-arid grassland. Oecologia, 158(1), 129-140. https://doi.org/10.1007/s00442-008-1116-9

Hewitson, B. C., Daron, J., Crane, R. G., Zermoglio, M. F., \& Jack, C. (2014). Interrogating empirical-statistical downscaling. Climatic Change, 122(4), 539-554.

https://doi.org/10.1007/s10584-013-1021-z

Huntzinger, D. N., Post, W. M., Wei, Y., Michalak, A. M., West, T. O., Jacobson, A. R., ... \& Hoffman, F. M. (2012). North American Carbon Program (NACP) regional interim synthesis: Terrestrial biospheric model intercomparison. Ecological Modelling, 232, 144157. https://doi.org/10.1016/j.ecolmodel.2012.02.004

Huxman, T. E., Snyder, K. A., Tissue, D., Leffler, A. J., Ogle, K., Pockman, W. T., ... \& Schwinning, S. (2004). Precipitation pulses and carbon fluxes in semiarid and arid ecosystems. Oecologia, 141(2), 254-268. https://doi.org/10.1007/s00442-004-1682-4

INEGI (2010). Conjunto Nacional de Uso de Suelo y Vegetación a escala 1:250,000, DGGINEGI, México. Serie IV.

IPCC (2013). Climate Change 2013: The Physical Science Basis. Contribution of Working Group I to the Fifth Assessment Report of the Intergovernmental Panel on Climate Change [Stocker, T.F., D. Qin, G.-K. Plattner, M. Tignor, S.K. Allen, J. Boschung, A. Nauels, Y. Xia, V. Bex and P.M. Midgley (eds.)]. Cambridge University Press, Cambridge, United Kingdom and New York, NY, USA, 1535 pp, doi:10.1017/CBO9781107415324.

This article is protected by copyright. All rights reserved. 
1060

1061

1062

1063

1064

1065

1066

1067

1068

1069

1070

1071

1072

1073

1074

1075

1076

1077

1078

1079

1080

1081

1082

1083

1084

1085

1086

1087

1088

1089

1090

1091

1092

1093

1094

1095

1096

1097

1098

1099

1100

1101

1102

1103

Ivanov, V. Y., Bras, R. L., \& Vivoni, E. R. (2008a). Vegetation-hydrology dynamics in complex terrain of semiarid areas: 1. A mechanistic approach to modeling dynamic feedbacks. Water Resources Research, 44(3). W03429, https://doi.org/10.1029/2006WR005588.

Ivanov, V. Y., Bras, R. L., \& Vivoni, E. R. (2008b). Vegetation-hydrology dynamics in complex terrain of semiarid areas: 1. A mechanistic approach to modeling dynamic feedbacks. Water Resources Research, 44(3). W03430, https://doi.org/10.1029/2006WR005595.

Jackson, R. B., Canadell, J., Ehleringer, J. R., Mooney, H. A., Sala, O. E., \& Schulze, E. D. (1996). A global analysis of root distributions for terrestrial biomes. Oecologia, 108(3), 389-411. https://doi.org/10.1007/BF00333714

Janssens, I. A., Lankreijer, H., Matteucci, G., Kowalski, A. S., Buchmann, N., Epron, D., ... \& Montagnani, L. (2001). Productivity overshadows temperature in determining soil and ecosystem respiration across European forests. Global Change Biology, 7(3), 269-278. https://doi.org/10.1046/j.1365-2486.2001.00412.x

Jenerette, G. D., Scott, R. L., \& Huete, A. R. (2010). Functional differences between summer and winter season rain assessed with MODIS-derived phenology in a semi-arid region. Journal of Vegetation Science, 21(1), 16-30. https://doi.org/10.1111/j.16541103.2009.01118.x

Kattge, J., \& Knorr, W. (2007). Temperature acclimation in a biochemical model of photosynthesis: a reanalysis of data from 36 species. Plant, Cell \& Environment, 30(9), 1176-1190. https://doi.org/10.1111/j.1365-3040.2007.01690.x

Kauwe, M. G., Medlyn, B. E., Zaehle, S., Walker, A. P., Dietze, M. C., Hickler, T., ... \& Smith, B. (2013). Forest water use and water use efficiency at elevated CO2: a model-data intercomparison at two contrasting temperate forest FACE sites. Global Change Biology, 19(6), 1759-1779. http://dx.doi.org/10.1111/gcb.12164

Keenan, T. F., Baker, I., Barr, A., Ciais, P., Davis, K., Dietze, M., ... \& Hufkens, K. (2012). Terrestrial biosphere model performance for inter-annual variability of land-atmosphere CO2 exchange. Global Change Biology, 18(6), 1971-1987. http://dx.doi.org/10.1111/j.1365-2486.2012.02678.x

Kunkel, K.E. (2016) Update to data originally published in: Kunkel, K.E., D.R. Easterling, K. Hubbard, and K. Redmond. 2004. Temporal variations in frost-free season in the United States: 1895-2000. Geophysical Research Letters, 31, L03201, doi:10.1029/2003GL018624.

Lavee, H., Imeson, A. C., \& Sarah, P. (1998). The impact of climate change on geomorphology and desertification along a mediterranean-arid transect. Land Degradation \& Development, 9(5), 407-422. https://doi.org/10.1002/(SICI)1099145X(199809/10)9:5<407::AID-LDR302>3.0.CO;2-6

Leakey, A. D., Ainsworth, E. A., Bernacchi, C. J., Rogers, A., Long, S. P., \& Ort, D. R. (2009). Elevated $\mathrm{CO} 2$ effects on plant carbon, nitrogen, and water relations: six important lessons from FACE. Journal of Experimental Botany, 60(10), 2859-2876. https://doi.org/10.1093/jxb/erp096

Lee, J. Y., \& Wang, B. (2014). Future change of global monsoon in the CMIP5. Climate Dynamics, 42(1-2), 101-119. https://doi.org/10.1007/s00382-012-1564-0 
Legates, D. R., \& McCabe, G. J. (1999). Evaluating the use of "goodness-of-fit" measures in hydrologic and hydroclimatic model validation. Water Resources Research, 35(1), 233241. https://doi.org/10.1029/1998WR900018

Lenton, T. M., \& Huntingford, C. (2003). Global terrestrial carbon storage and uncertainties in its temperature sensitivity examined with a simple model. Global Change Biology, 9(10), 1333-1352. https://doi.org/10.1046/j.1365-2486.2003.00674.x

Li, T., Grant, R. F., \& Flanagan, L. B. (2004). Climate impact on net ecosystem productivity of a semi-arid natural grassland: modeling and measurement. Agricultural and Forest Meteorology, 126(1), 99-116. https://doi.org/10.1016/j.agrformet.2004.06.005

Liu, W., Zhang, Z. H. E., \& Wan, S. (2009). Predominant role of water in regulating soil and microbial respiration and their responses to climate change in a semiarid grassland. Global Change Biology, 15(1), 184-195. https://doi.org/10.1111/j.13652486.2008.01728.x

Loescher, H. W., Oberbauer, S. F., Gholz, H. L., \& Clark, D. B. (2003). Environmental controls on net ecosystem-level carbon exchange and productivity in a Central American tropical wet forest. Global Change Biology, 9(3), 396-412. https://doi.org/10.1046/j.13652486.2003.00599.x

Lu, X., Wang, L., \& McCabe, M. F. (2016). Elevated CO2 as a driver of global dryland greening. Scientific Reports, 6, 20716. https://doi.org/10.1038/srep20716

Luo, Y., Gerten, D., Le Maire, G., Parton, W. J., Weng, E., Zhou, X., ... \& Dukes, J. S. (2008). Modeled interactive effects of precipitation, temperature, and [CO2] on ecosystem carbon and water dynamics in different climatic zones. Global Change Biology, 14(9), 19861999. https://doi.org/ 10.1111/j.1365-2486.2008.01629.x

Luo, Y., Wan, S., Hui, D., \& Wallace, L. L. (2001). Acclimatization of soil respiration to warming in a tall grass prairie. Nature, 413(6856), 622-625. https://doi.org/10.1038/35098065

Lloyd, J., \& Taylor, J. A. (1994). On the temperature dependence of soil respiration. Functional Ecology, 8(3), 315-323. https://doi.org/10.2307/2389824

Maloney, E. D., Camargo, S. J., Chang, E., Colle, B., Fu, R., Geil, K. L., ... \& Kinter, J. (2014). North American climate in CMIP5 experiments: Part III: Assessment of twenty-firstcentury projections. Journal of Climate, 27(6), 2230-2270. https://doi.org/10.1175/JCLID-13-00273.1

Manzoni, S., Porporato, A., D'Odorico, P., Laio, F., \& Rodriguez-Iturbe, I. (2004). Soil nutrient cycles as a nonlinear dynamical system. Nonlinear Processes in Geophysics, 11(5/6), 589-598.

Maraun, D. (2013). Bias correction, quantile mapping, and downscaling: revisiting the inflation issue. Journal of Climate, 26(6), 2137-2143. https://doi.org/10.1175/JCLI-D-12-00821.1

Martínez-Yrízar, A., Núñez, S., \& Burquez, A. (2007). Leaf litter decomposition in a southern Sonoran Desert ecosystem, northwestern Mexico: Effects of habitat and litter quality. Acta Oecologica, 32(3), 291-300. https://doi.org/10.1016/j.actao.2007.05.010

Martínez-Yrízar, A., Núñez, S., Miranda, H., \& Búrquez, A. (1999). Temporal and spatial variation of litter production in Sonoran Desert communities. Plant Ecology, 145(1), 3748. https://doi.org/10.1023/A:1009896201047

Maseyk, K., Hemming, D., Angert, A., Leavitt, S. W., \& Yakir, D. (2011). Increase in water-use efficiency and underlying processes in pine forests across a precipitation gradient in the 
dry Mediterranean region over the past 30 years. Oecologia, 167(2), 573-585. https://doi.org/10.1007/s00442-011-2010-4

Massman, W. J., \& Lee, X. (2002). Eddy covariance flux corrections and uncertainties in longterm studies of carbon and energy exchanges. Agricultural and Forest Meteorology, 113(1), 121-144. https://doi.org/10.1016/S0168-1923(02)00105-3

McCulley, R. L., Archer, S. R., Boutton, T. W., Hons, F. M., \& Zuberer, D. A. (2004). Soil respiration and nutrient cycling in wooded communities developing in grassland. Ecology, 85(10), 2804-2817. https://doi.org/10.1890/03-0645

Méndez-Barroso, L. A., Vivoni, E. R., Watts, C. J., \& Rodríguez, J. C. (2009). Seasonal and interannual relations between precipitation, surface soil moisture and vegetation dynamics in the North American monsoon region. Journal of Hydrology, 377(1), 59-70. https://doi.org/10.1016/j.jhydrol.2009.08.009

Méndez-Barroso, L. A., Vivoni, E. R., Robles-Morua, A., Mascaro, G., Yépez, E. A., Rodríguez, J. C., ... \& Saíz-Hernández, J. A. (2014). A modeling approach reveals differences in evapotranspiration and its partitioning in two semiarid ecosystems in Northwest Mexico. Water Resources Research, 50(4), 3229-3252. https://doi.org/10.1002/2013WR014838

Miranda, J. D. D., Armas, C., Padilla, F. M., \& Pugnaire, F. I. (2011). Climatic change and rainfall patterns: effects on semi-arid plant communities of the Iberian Southeast. Journal of Arid Environments, 75(12), 1302-1309. https://doi.org/10.1016/j.jaridenv.2011.04.022

Mitchell, K. E., Lohmann, D., Houser, P. R., Wood, E. F., Schaake, J. C., Robock, A., ... \& Higgins, R. W. (2004). The multi-institution North American Land Data Assimilation System (NLDAS): Utilizing multiple GCIP products and partners in a continental distributed hydrological modeling system. Journal of Geophysical Research: Atmospheres, 109(D7). https://doi.org/10.1029/2003JD003823

Morgan, J. A., Mosier, A. R., Milchunas, D. G., LeCain, D. R., Nelson, J. A., \& Parton, W. J. (2004). CO2 enhances productivity of the shortgrass steppe, alters species composition, and reduces forage digestibility. Ecological Applications, 14, 208-219.

Morgan, J. A., LeCain, D. R., Pendall, E., Blumenthal, D. M., Kimball, B. A., Carrillo, Y., ... \& West, M. (2011). C4 grasses prosper as carbon dioxide eliminates desiccation in warmed semi-arid grassland. Nature, 476(7359), 202-205. http://dx.doi.org/10.1038/nature10274

Moritz, C., \& Agudo, R. (2013). The future of species under climate change: resilience or decline?. Science, 341(6145), 504-508. https://doi.org/10.1126/science.1237190

Mowll, W., Blumenthal, D. M., Cherwin, K., Smith, A., Symstad, A. J., Vermeire, L. T., ... \& Knapp, A. K. (2015). Climatic controls of aboveground net primary production in semiarid grasslands along a latitudinal gradient portend low sensitivity to warming. Oecologia, 177(4), 959-969. https://doi.org/10.1007/s0044

Mueller, K. E., Blumenthal, D. M., Pendall, E., Carrillo, Y., Dijkstra, F. A., Williams, D. G., ... \& Morgan, J. A. (2016). Impacts of warming and elevated CO2 on a semi-arid grassland are non-additive, shift with precipitation, and reverse over time. Ecology Letters, 19(8), 956-966. https://doi.org/10.1111/ele.12634

Nagol, J. R., Vermote, E. F., \& Prince, S. D. (2009). Effects of atmospheric variation on AVHRR NDVI data. Remote Sensing of Environment, 113(2), 392-397. https://doi.org/10.1016/j.rse.2008.10.007

Nayak, R. K., Patel, N. R., \& Dadhwal, V. K. (2015). Spatio-temporal variability of net ecosystem productivity over India and its relationship to climatic 
variables. Environmental Earth Sciences, 74(2), 1743-1753. https://doi.org/10.1007/s12665-015-4182-4

Newingham, B. A., Vanier, C. H., Charlet, T. N., Ogle, K., Smith, S. D., \& Nowak, R. S. (2013). No cumulative effect of 10 years of elevated [CO2] on perennial plant biomass components in the Mojave Desert. Global Change Biology, 19(7), 2168-2181. https://doi.org/10.1111/gcb.12177

Novick, K. A., Ficklin, D. L., Stoy, P. C., Williams, C. A., Bohrer, G., Oishi, A. C., Papuga, S. A., Blanken, P. D., Noormets, A., Sulman, B. N., Scott, R. L., Wang, L., \& Phillips, R. P. (2016). The increasing importance of atmospheric demand for ecosystem water and carbon fluxes. Nature Climate Change, 6(11), 1023-1027. http://dx.doi.org/10.1038/nclimate3114

Núñez, S., Martínez-Yrízar, A., Búrquez, A., \& García-Oliva, F. (2001). Carbon mineralization in the southern Sonoran Desert. Acta Oecologica, 22(5), 269-276. https://doi.org/10.1016/S1146-609X(01)01122-5

Ogle, K., \& Reynolds, J. F. (2002). Desert dogma revisited: coupling of stomatal conductance and photosynthesis in the desert shrub, Larrea tridentata. Plant, Cell \& Environment, 25(7), 909-921. https://doi.org/10.1046/j.1365-3040.2002.00876.x

ORNL DAAC. 2008. MODIS Collection 5 Land Products Global Subsetting and Visualization Tool. ORNL DAAC, Oak Ridge, Tennessee, USA. Accessed January 18, 2017. http://dx.doi.org/10.3334/ORNLDAAC/1241

Pachauri, R. K., Allen, M. R., Barros, V. R., Broome, J., Cramer, W., Christ, R., ... \& Dubash, N. K. (2014). Climate change 2014: synthesis report. Contribution of Working Groups I, II and III to the fifth assessment report of the Intergovernmental Panel on Climate Change (p. 151). IPCC.

Parolari, A. J., \& Porporato, A. (2016). Forest soil carbon and nitrogen cycles under biomass harvest: stability, transient response, and feedback. Ecological Modelling, 329, 64-76. https://doi.org/10.1016/j.ecolmodel.2016.03.003

Pavón, N. P., Briones, O., \& Flores-Rivas, J. (2005). Litterfall production and nitrogen content in an intertropical semi-arid Mexican scrub. Journal of Arid Environments, 60(1), 1-13. https://doi.org/10.1016/j.jaridenv.2004.03.004

Perez-Ruiz, E. R., Garatuza-Payan, J., Watts, C. J., Rodriguez, J. C., Yepez, E. A., \& Scott, R. L. (2010). Carbon dioxide and water vapour exchange in a tropical dry forest as influenced by the North American Monsoon System (NAMS). Journal of Arid Environments, 74(5), 556-563. https://doi.org/10.1016/j.jaridenv.2009.09.029

Plaut, J. A., Yepez, E. A., Hill, J., Pangle, R., Sperry, J. S., Pockman, W. T., \& Mcdowell, N. G. (2012). Hydraulic limits preceding mortality in a piñon-juniper woodland under experimental drought. Plant, Cell \& Environment, 35(9), 1601-1617. https://doi.org/10.1111/j.1365-3040.2012.02512.x

Ponce-Campos, G. E., Moran, M. S., Huete, A., Zhang, Y., Bresloff, C., Huxman, T. E., ... \& Scalley, T. H. (2013). Ecosystem resilience despite large-scale altered hydroclimatic conditions. Nature, 494(7437), 349-352. https://doi.org/10.1038/nature11836

Porporato, A., D'odorico, P., Laio, F., \& Rodriguez-Iturbe, I. (2003). Hydrologic controls on soil carbon and nitrogen cycles. I. Modeling scheme. Advances in Water Resources, 26(1), 45-58. https://doi.org/10.1016/S0309-1708(02)00094-5 
Poulter, B., Frank, D., Ciais, P., Myneni, R. B., Andela, N., Bi, J., ... \& Running, S. W. (2014). Contribution of semi-arid ecosystems to interannual variability of the global carbon cycle. Nature, 509(7502), 600-603. https://doi.org/10.1038/nature13376

Rawls, W. J., Brakensiek, D. L., \& Saxtonn, K. E. (1982). Estimation of soil water properties. Transactions of the ASAE, 25(5), 1316-1320. https://doi.org/10.13031/2013.33720

Reichstein, M., Falge, E., Baldocchi, D., Papale, D., Aubinet, M., Berbigier, P., ... \& Grünwald, T. (2005). On the separation of net ecosystem exchange into assimilation and ecosystem respiration: review and improved algorithm. Global Change Biology, 11(9), 1424-1439. https://doi.org/10.1111/j.1365-2486.2005.001002.x

Reichstein, M., Rey, A., Freibauer, A., Tenhunen, J., Valentini, R., Banza, J., ... \& Joffre, R. (2003). Modeling temporal and large-scale spatial variability of soil respiration from soil water availability, temperature and vegetation productivity indices. Global Biogeochemical Cycles, 17, 1104. https://doi.org/10.1029/2003GB002035

Robertson, T. R., Bell, C. W., Zak, J. C., \& Tissue, D. T. (2009). Precipitation timing and magnitude differentially affect aboveground annual net primary productivity in three perennial species in a Chihuahuan Desert grassland. New Phytologist, 181(1), 230-242. https://doi.org/10.1111/j.1469-8137.2008.02643.x

Robles-Morua, A., Vivoni, E. R., \& Mayer, A. S. (2012). Distributed hydrologic modeling in northwest Mexico reveals the links between runoff mechanisms and evapotranspiration. Journal of Hydrometeorology, 13(3), 785-807. https://doi.org/10.1175/JHM-D-11-0112.1

Robles-Morua, A., Che, D., Mayer, A. S., \& Vivoni, E. R. (2015). Hydrological assessment of proposed reservoirs in the Sonora River Basin, Mexico, under historical and future climate scenarios. Hydrological Sciences Journal, 60(1), 50-66. https://doi.org/10.1080/02626667.2013.878462

Porporato, A., D’odorico, P., Laio, F., Ridolfi, L., \& Rodriguez-Iturbe, I. (2003). Ecohydrology of water-controlled ecosystems. Advances in Water Resources, 25(8), 1335-1348. https://doi.org/10.1016/S0309-1708(02)00058-1

Rohr, T., Manzoni, S., Feng, X., Menezes, R. S., \& Porporato, A. (2013). Effect of rainfall seasonality on carbon storage in tropical dry ecosystems. Journal of Geophysical Research: Biogeosciences, 118(3), 1156-1167. https://doi.org/10.1002/jgrg.20091

Ross, I., Misson, L., Rambal, S., Arneth, A., Scott, R. L., Carrara, A., ... \& Genesio, L. (2012). How do variations in the temporal distribution of rainfall events affect ecosystem fluxes in seasonally water-limited Northern Hemisphere shrublands and forests. Biogeosciences, 9, 1007-1024. http://dx.doi.org/10.5194/bg-9-1007-2012

Ryan, M. G. (1991). Effects of climate change on plant respiration. Ecological Applications, 1(2), 157-167. http://doi.org/10.2307/1941808

Sacks, W. J., Schimel, D. S., \& Monson, R. K. (2007). Coupling between carbon cycling and climate in a high-elevation, subalpine forest: a model-data fusion analysis. Oecologia, 151(1), 54-68. https://doi.org/10.1007/s00442-006-0565-2

Sage, R. F., \& Kubien, D. S. (2007). The temperature response of C3 and C4 photosynthesis. Plant, Cell \& Environment, 30(9), 1086-1106. https://doi.org/10.1111/j.1365-3040.2007.01682.x 
Sage, R. F., Sharkey, T. D., \& Seemann, J. R. (1989). Acclimation of photosynthesis to elevated CO 2 in five C 3 species. Plant Physiology, 89(2), 590-596. https://doi.org/10.1104/pp.89.2.590

Salvucci, M. E., \& Crafts-Brandner, S. J. (2004). Relationship between the heat tolerance of photosynthesis and the thermal stability of Rubisco activase in plants from contrasting thermal environments. Plant Physiology, 134(4), 1460-1470. https://doi.org/10.1104/pp.103.038323

Seneviratne, S. I., Corti, T., Davin, E. L., Hirschi, M., Jaeger, E. B., Lehner, I., ... \& Teuling, A. J. (2010). Investigating soil moisture-climate interactions in a changing climate: A review. Earth-Science Reviews, 99(3), 125-161. https://doi.org/10.1016/j.earscirev.2010.02.004

Scott, R. L., Biederman, J. A., Hamerlynck, E. P., \& Barron-Gafford, G. A. (2015). The carbon balance pivot point of southwestern US semiarid ecosystems: Insights from the 21st century drought. Journal of Geophysical Research: Biogeosciences, 120(12), 2612-2624. https://doi.org/10.1002/2015JG003181

Scott, R. L., Edwards, E. A., Shuttleworth, W. J., Huxman, T. E., Watts, C., \& Goodrich, D. C. (2004). Interannual and seasonal variation in fluxes of water and carbon dioxide from a riparian woodland ecosystem. Agricultural and Forest Meteorology, 122(1), 65-84. https://doi.org/10.1016/j.agrformet.2003.09.001

Scott, R. L., Hamerlynck, E. P., Jenerette, G. D., Moran, M. S., \& Barron-Gafford, G. A. (2010). Carbon dioxide exchange in a semidesert grassland through drought-induced vegetation change. Journal of Geophysical Research: Biogeosciences, 115, G03026, https://doi.org/10.1029/2010JG001348

Scott, R. L., Jenerette, G. D., Potts, D. L., \& Huxman, T. E. (2009). Effects of seasonal drought on net carbon dioxide exchange from a woody-plant-encroached semiarid grassland. Journal of Geophysical Research: Biogeosciences, 114, G04004, https://doi.org/ doi:10.1029/2008JG000900

Schwinning, S., \& Ehleringer, J. R. (2001). Water use trade-offs and optimal adaptations to pulse-driven arid ecosystems. Journal of Ecology, 89(3), 464-480. https://doi.org/10.1046/j.1365-2745.2001.00576.x

Seager, R., Ting, M., Held, I., Kushnir, Y., Lu, J., Vecchi, G., ... \& Li, C. (2007). Model projections of an imminent transition to a more arid climate in southwestern North America. Science, 316(5828), 1181-1184. https://doi.org/10.1126/science.1139601

Serrat-Capdevila, A., Scott, R. L., Shuttleworth, W. J., \& Valdés, J. B. (2011). Estimating evapotranspiration under warmer climates: Insights from a semi-arid riparian system. Journal of Hydrology, 399(1), 1-11. https://doi.org/10.1016/j.jhydrol.2010.12.021

Shi, Z., Thomey, M. L., Mowll, W., Litvak, M., Brunsell, N. A., Collins, S. L., ... \& Luo, Y. (2013). Differential effects of extreme drought on production and respiration: synthesis and modeling analysis. Biogeosciences Discussions, 10(10), 16043-16074. https://doi.org/10.5194/bg-11-621-2014, 2014

Sivandran, G., \& Bras, R. L. (2012) Identifying the optimal spatially and temporally invariant root distributions for a semiarid environment. Water Resources Research, 48, W12525. http://dx.doi.org/10.1029/2012WR012055. 
Slot, M., \& Kitajima, K. (2015). General patterns of acclimation of leaf respiration to elevated temperatures across biomes and plant types. Oecologia, 177(3), 885-900. https://doi.org/10.1007/s00442-014-3159-4

Smith, S. D., Huxman, T. E., Zitzer, S. F., Charlet, T. N., Housman, D. C., Coleman, J. S., ... \& Nowak, R. S. (2000). Elevated CO2 increases productivity and invasive species success in an arid ecosystem. Nature, 408(6808), 79-82. https://doi.org/10.1038/35040544

Spitters, C. J. T., Toussaint, H. A. J. M., \& Goudriaan, J. (1986). Separating the diffuse and direct component of global radiation and its implications for modeling canopy photosynthesis Part I. Components of incoming radiation. Agricultural and Forest Meteorology, 38(1-3), 217-229. https://doi.org/10.1016/0168-1923(86)90060-2

Sponseller, R. A. (2007). Precipitation pulses and soil CO2 flux in a Sonoran Desert ecosystem. Global Change Biology, 13(2), 426-436. https://doi.org/10.1111/j.13652486.2006.01307.x

Steinweg, J. M., Plante, A. F., Conant, R. T., Paul, E. A., \& Tanaka, D. L. (2008). Patterns of substrate utilization during long-term incubations at different temperatures. Soil Biology and Biochemistry, 40(11), 2722-2728. https://doi.org/10.1016/j.soilbio.2008.07.002

Stoy, P. C., Katul, G. G., Siqueira, M. B., Juang, J. Y., Novick, K. A., Uebelherr, J. M., \& Oren, R. (2006). An evaluation of models for partitioning eddy covariance-measured net ecosystem exchange into photosynthesis and respiration. Agricultural and Forest Meteorology, 14l(1), 2-18. https://doi.org/10.1016/j.agrformet.2006.09.001

Stoy, P. C., Richardson, A. D., Baldocchi, D. D., Katul, G. G., Stanovick, J., Mahecha, M. D., ... \& Arriga, N. (2009). Biosphere-atmosphere exchange of CO2 in relation to climate. Biogeosciences. 6, 2297-2312. https://doi.org/10.5194/bg-6-2297-2009

Tang, Q., Vivoni, E. R., Muñoz-Arriola, F., \& Lettenmaier, D. P. (2012). Predictability of evapotranspiration patterns using remotely sensed vegetation dynamics during the North American monsoon. Journal of Hydrometeorology, 13(1), 103-121. https://doi.org/10.1175/JHM-D-11-032.1

Taylor, K. E., Stouffer, R. J., \& Meehl, G. A. (2012). An overview of CMIP5 and the experiment design. Bulletin of the American Meteorological Society, 93(4), 485-498. https://doi.org/10.1175/BAMS-D-11-00094.1

Thiessen, S., Gleixner, G., Wutzler, T., \& Reichstein, M. (2013). Both priming and temperature sensitivity of soil organic matter decomposition depend on microbial biomass-An incubation study. Soil Biology and Biochemistry, 57, 739-748. https://doi.org/10.1016/j.soilbio.2012.10.029

Thomey, M. L., Collins, S. L., Vargas, R., Johnson, J. E., Brown, R. F., Natvig, D. O., \& Friggens, M. T. (2011). Effect of precipitation variability on net primary production and soil respiration in a Chihuahuan Desert grassland. Global Change Biology, 17(4), 15051515. https://doi.org/10.1111/j.1365-2486.2010.02363.x

Unger, S., Máguas, C., Pereira, J. S., David, T. S., \& Werner, C. (2010). The influence of precipitation pulses on soil respiration-Assessing the "Birch effect" by stable carbon isotopes. Soil Biology and Biochemistry, 42(10), 1800-1810. https://doi.org/10.1016/j.soilbio.2010.06.019

Vargas, R., Sonnentag, O., Abramowitz, G., Carrara, A., Chen, J. M., Ciais, P., Correia, A., Keenan, T. F., Kobayashi, H. \& Ourcival, J.-M. (2013). Drought influences the accuracy of simulated ecosystem fluxes: a model-data meta-analysis for Mediterranean oak woodlands. Ecosystems, 16, 749-764. https://doi.org/10.1007/s10021-013-9648-1 
Verduzco, V. S., Garatuza-Payán, J., Yépez, E. A., Watts, C. J., Rodríguez, J. C., Robles-Morua, A., \& Vivoni, E. R. (2015). Variations of net ecosystem production due to seasonal precipitation differences in a tropical dry forest of northwest Mexico. Journal of Geophysical Research: Biogeosciences, 120(10), 2081-2094. https://doi.org/10.1002/2015JG003119

Verduzco, V. S. (2016). Climate Variability Impacts on Net Ecosystem Production in Northwest Mexico. Ph.D. Dissertation in Biotechnology, Instituto Technológico de Sonora, Ciudad Obregón, Sonora, México, 169 pp.

Villarreal, S., Vargas, R., Yepez, E. A., Acosta, J. S., Castro, A., Escoto-Rodriguez, M., ... \& Vivoni, E. R. (2016). Contrasting precipitation seasonality influences evapotranspiration dynamics in water-limited shrublands. Journal of Geophysical Research: Biogeosciences, 121(2), 494-508. https://doi.org/10.1002/2015JG003169

Vivoni, E. R., Ivanov, V. Y., Bras, R. L., \& Entekhabi, D. (2005). On the effects of triangulated terrain resolution on distributed hydrologic model response. Hydrological Processes, 19(11), 2101-2122. 10.1002/hyp.5671 10.1002/hyp.5671

Vivoni, E. R., Entekhabi, D., Bras, R. L., Ivanov, V. Y., Van Horne, M. P., Grassotti, C., \& Hoffman, R. N. (2006). Extending the predictability of hydrometeorological flood events using radar rainfall nowcasting. Journal of Hydrometeorology, 7(4), 660-677. https://doi.org/10.1175/JHM514.1

Vivoni, E. R., Moreno, H. A., Mascaro, G., Rodriguez, J. C., Watts, C. J., Garatuza-Payan, J., \& Scott, R. L. (2008). Observed relation between evapotranspiration and soil moisture in the North American monsoon region. Geophysical Research Letters, 35(22), L22403, https://doi.org/10.1029/2008GL036001.

Vivoni, E. R., Rodríguez, J. C., \& Watts, C. J. (2010). On the spatiotemporal variability of soil moisture and evapotranspiration in a mountainous basin within the North American monsoon region. Water Resources Research, 46(2), W02509, https://doi.org/10.1029/2009WR008240.

Vivoni, E. R., Watts, C. J., Rodríguez, J. C., Garatuza-Payan, J., Méndez-Barroso, L. A., \& SaizHernández, J. A. (2010). Improved land-atmosphere relations through distributed footprint sampling in a subtropical scrubland during the North American monsoon. Journal of Arid Environments, 74(5), 579-584. https://doi.org/10.1016/j.jaridenv.2009.09.031

Wang, D., Heckathorn, S. A., Wang, X., \& Philpott, S. M. (2012). A meta-analysis of plant physiological and growth responses to temperature and elevated CO2. Oecologia, 169(1), 1-13. https://doi.org/10.1007/s00442-011-2172-0.

Wang, Y. P., \& Leuning, R. (1998). A two-leaf model for canopy conductance, photosynthesis and partitioning of available energy I: Model description and comparison with a multilayered model. Agricultural and Forest Meteorology, 91(1), 89-111. https://doi.org/10.1016/S0168-1923(98)00061-6

Watts, C. J., Scott, R. L., Garatuza-Payan, J., Rodriguez, J. C., Prueger, J. H., Kustas, W. P., \& Douglas, M. (2007). Changes in vegetation condition and surface fluxes during NAME 2004. Journal of Climate, 20(9), 1810-1820. https://doi.org/10.1175/JCLI4088.1

Webb, E. K., Pearman, G. I., \& Leuning, R. (1980). Correction of flux measurements for density effects due to heat and water vapour transfer. Quarterly Journal of the Royal Meteorological Society, 106(447), 85-100. https://doi.org/10.1002/qj.49710644707 
Werk, K. S., Ehleringer, J., Forseth, I. N., \& Cook, C. S. (1983). Photosynthetic characteristics of Sonoran Desert winter annuals. Oecologia, 59(1), 101-105. https://doi.org/10.1007/BF00388081

Wilcke, R. A. I., Mendlik, T., \& Gobiet, A. (2013). Multi-variable error correction of regional climate models. Climatic Change, 120(4), 871-887. https://doi.org/10.1007/s10584-0130845-X

Wilczak, J. M., Oncley, S. P., \& Stage, S. A. (2001). Sonic anemometer tilt correction algorithms. Boundary-Layer Meteorology, 99(1), 127-150. https://doi.org/10.1023/A:1018966204465

Williams, A. P., Allen, C. D., Macalady, A. K., Griffin, D., Woodhouse, C. A., Meko, D. M., ... \& Dean, J. S. (2013). Temperature as a potent driver of regional forest drought stress and tree mortality. Nature Climate Change, 3(3), 292-297. https://doi.org/10.1038/nclimate1693

Wullschleger, S. D., Gunderson, C. A., Hanson, P. J., Wilson, K. B., \& Norby, R. J. (2002). Sensitivity of stomatal and canopy conductance to elevated $\mathrm{CO} 2$ concentrationinteracting variables and perspectives of scale. New Phytologist, 153(3), 485-496. https://doi.org/10.1046/j.0028-646X.2001.00333.x

Wu, J., Linden, L. V. D., Lasslop, G., Carvalhais, N., Pilegaard, K., Beier, C., \& Ibrom, A. (2012). Effects of climate variability and functional changes on the interannual variation of the carbon balance in a temperate deciduous forest. Biogeosciences, 9(1), 13-28. https://doi.org/10.5194/bg-9-13-2012

Wu, Z., Dijkstra, P., Koch, G. W., Penuelas, J., \& Hungate, B. A. (2011). Responses of terrestrial ecosystems to temperature and precipitation change: a meta-analysis of experimental manipulation. Global Change Biology, 17(2), 927-942. https://doi.org/10.1111/j.13652486.2010.02302.x

Xiao, J., Zhuang, Q., Law, B. E., Baldocchi, D. D., Chen, J., Richardson, A. D., ... \& Oren, R. (2011). Assessing net ecosystem carbon exchange of US terrestrial ecosystems by integrating eddy covariance flux measurements and satellite observations. Agricultural and Forest Meteorology, 151(1), 60-69. https://doi.org/10.1016/j.agrformet.2010.09.002

Xie, J., Zha, T., Jia, X., Qian, D., Wu, B., Zhang, Y., ... \& Peltola, H. (2015). Irregular precipitation events in control of seasonal variations in $\mathrm{CO} 2$ exchange in a cold desertshrub ecosystem in northwest China. Journal of Arid Environments, 120, 33-41. https://doi.org/10.1016/j.jaridenv.2015.04.009

Xu, C., McDowell, N. G., Sevanto, S., \& Fisher, R. A. (2013). Our limited ability to predict vegetation dynamics under water stress. New Phytologist, 200(2), 298-300. https://doi.org/10.1111/nph.12450

Xu, L., \& Baldocchi, D. D. (2004). Seasonal variation in carbon dioxide exchange over a Mediterranean annual grassland in California. Agricultural and Forest Meteorology, 123(1), 79-96. https://doi.org/10.1016/j.agrformet.2003.10.004

Xu, Z., Shimizu, H., Ito, S., Yagasaki, Y., Zou, C., Zhou, G., \& Zheng, Y. (2014). Effects of elevated $\mathrm{CO} 2$, warming and precipitation change on plant growth, photosynthesis and peroxidation in dominant species from North China grassland. Planta, 239(2), 421-435. https://doi.org/10.1007/s00425-013-1987-9

Yamori, W., Hikosaka, K., \& Way, D. A. (2014). Temperature response of photosynthesis in C3, $\mathrm{C} 4$, and CAM plants: temperature acclimation and temperature 
adaptation. Photosynthesis Research, 119(1-2), 101-117.

https://doi.org/10.1007/s11120-013-9874-6

Yang, Y., Guan, H., Batelaan, O., McVicar, T. R., Long, D., Piao, S., ... \& Simmons, C. T. (2016). Contrasting responses of water use efficiency to drought across global terrestrial ecosystems. Scientific Reports, 6, 23284. https://doi.org/10.1038/srep23284

Yepez, E. A., Scott, R. L., Cable, W. L., \& Williams, D. G. (2007). Intraseasonal variation in water and carbon dioxide flux components in a semiarid riparian woodland. Ecosystems, 10(7), 1100-1115. https://doi.org/10.1007/s10021-007-9079-y

Zhang, X., Niu, G. Y., Elshall, A. S., Ye, M., Barron-Gafford, G. A., \& Pavao-Zuckerman, M. (2014). Assessing five evolving microbial enzyme models against field measurements from a semiarid savannah-What are the mechanisms of soil respiration pulses?. Geophysical Research Letters, 41(18), 6428-6434. https://doi.org/10.1002/2014GL061399

Zhou, X., Wan, S., \& Luo, Y. (2007). Source components and interannual variability of soil CO2 efflux under experimental warming and clipping in a grassland ecosystem. Global Change Biology, 13(4), 761-775. https://doi.org/10.1111/j.1365-2486.2007.01333.x

Zhou, Z., Jiang, L., Du, E., Hu, H., Li, Y., Chen, D., \& Fang, J. (2013). Temperature and substrate availability regulate soil respiration in the tropical mountain rainforests, Hainan Island, China. Journal of Plant Ecology, 6(5), 325-334. https://doi.org/10.1093/jpe/rtt034

This article is protected by copyright. All rights reserved. 


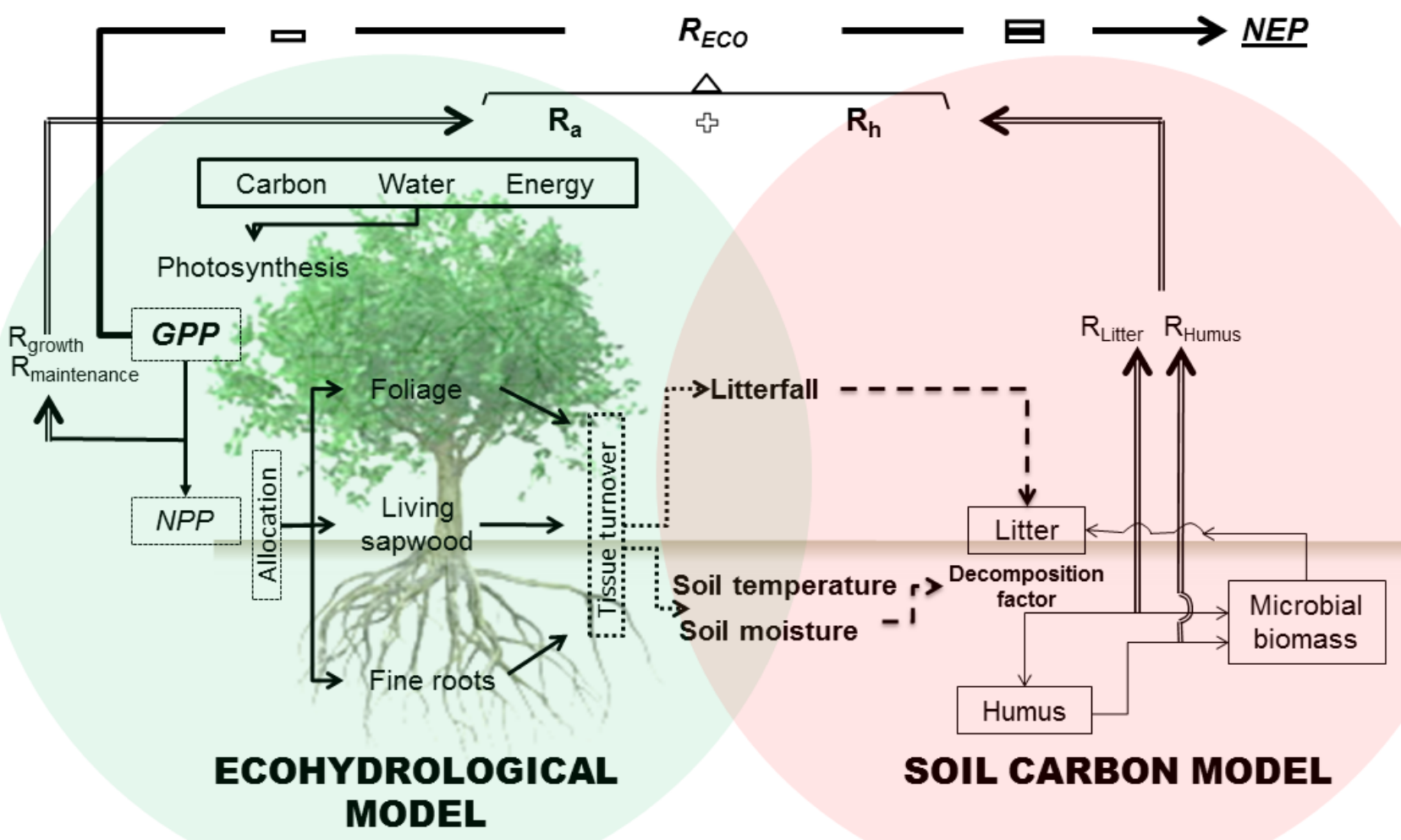

2017JG004361-f01-z-.tif

This article is protected by copyright. All rights reserved. 


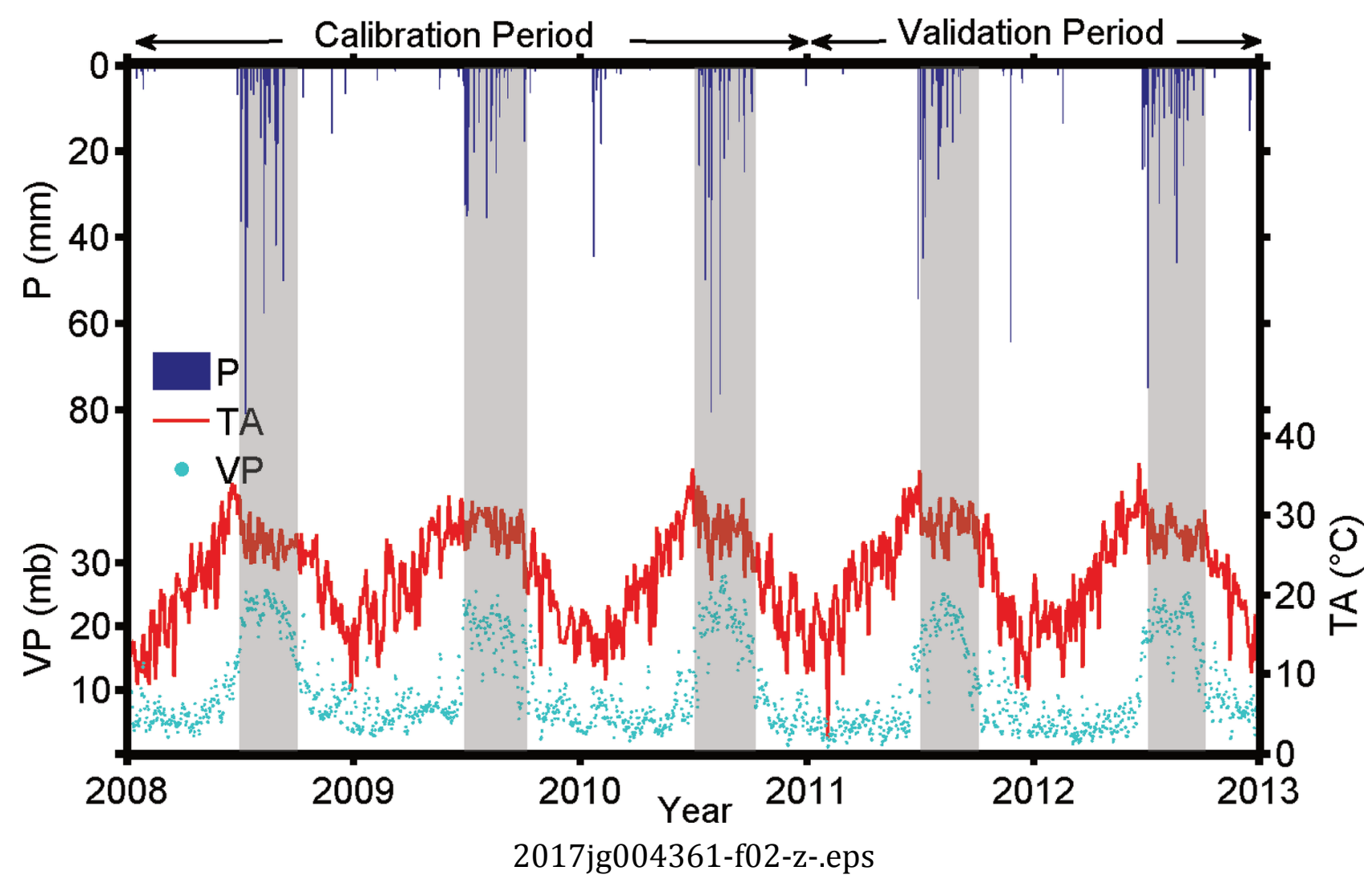

This article is protected by copyright. All rights reserved. 


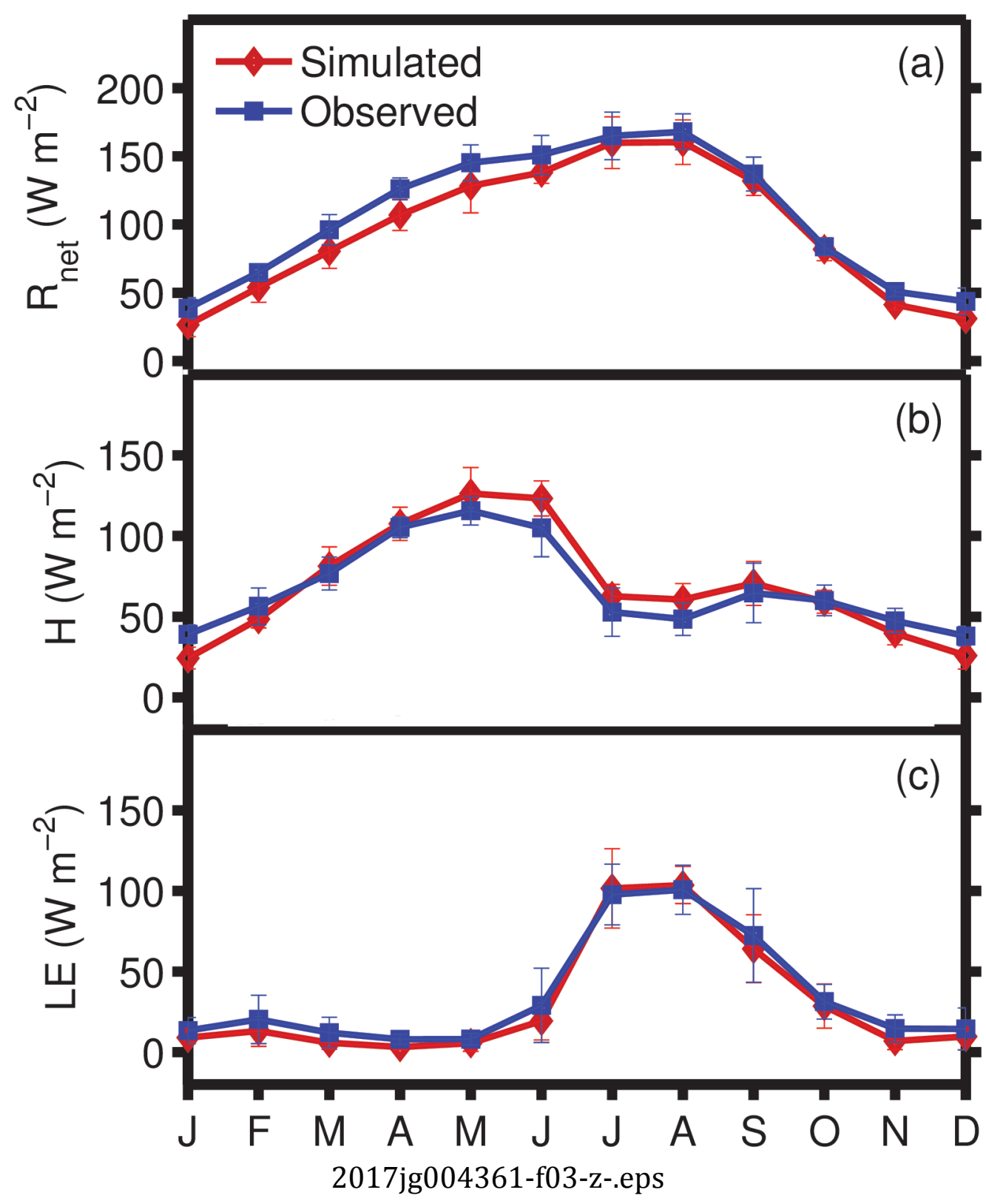

This article is protected by copyright. All rights reserved. 


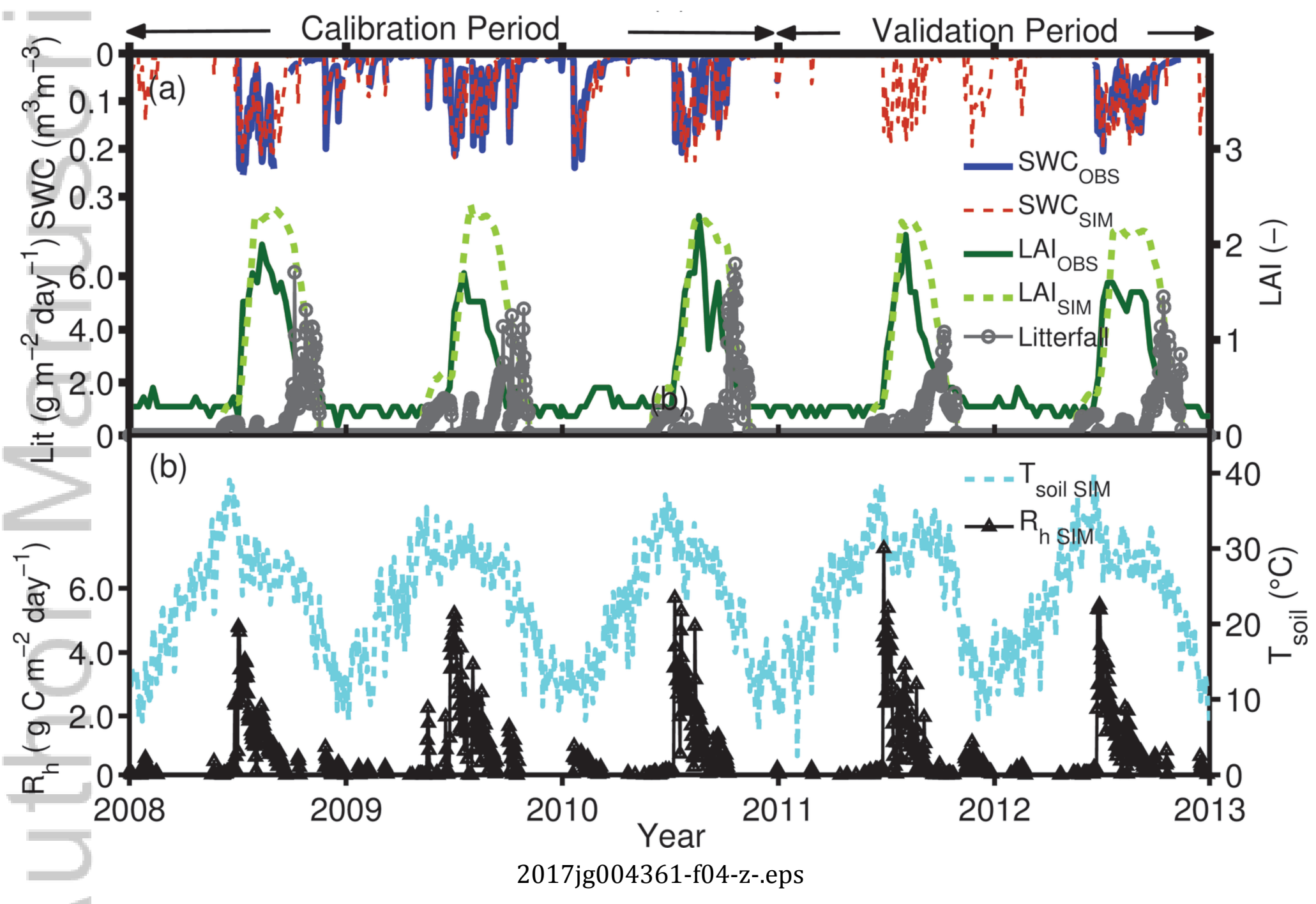

This article is protected by copyright. All rights reserved. 

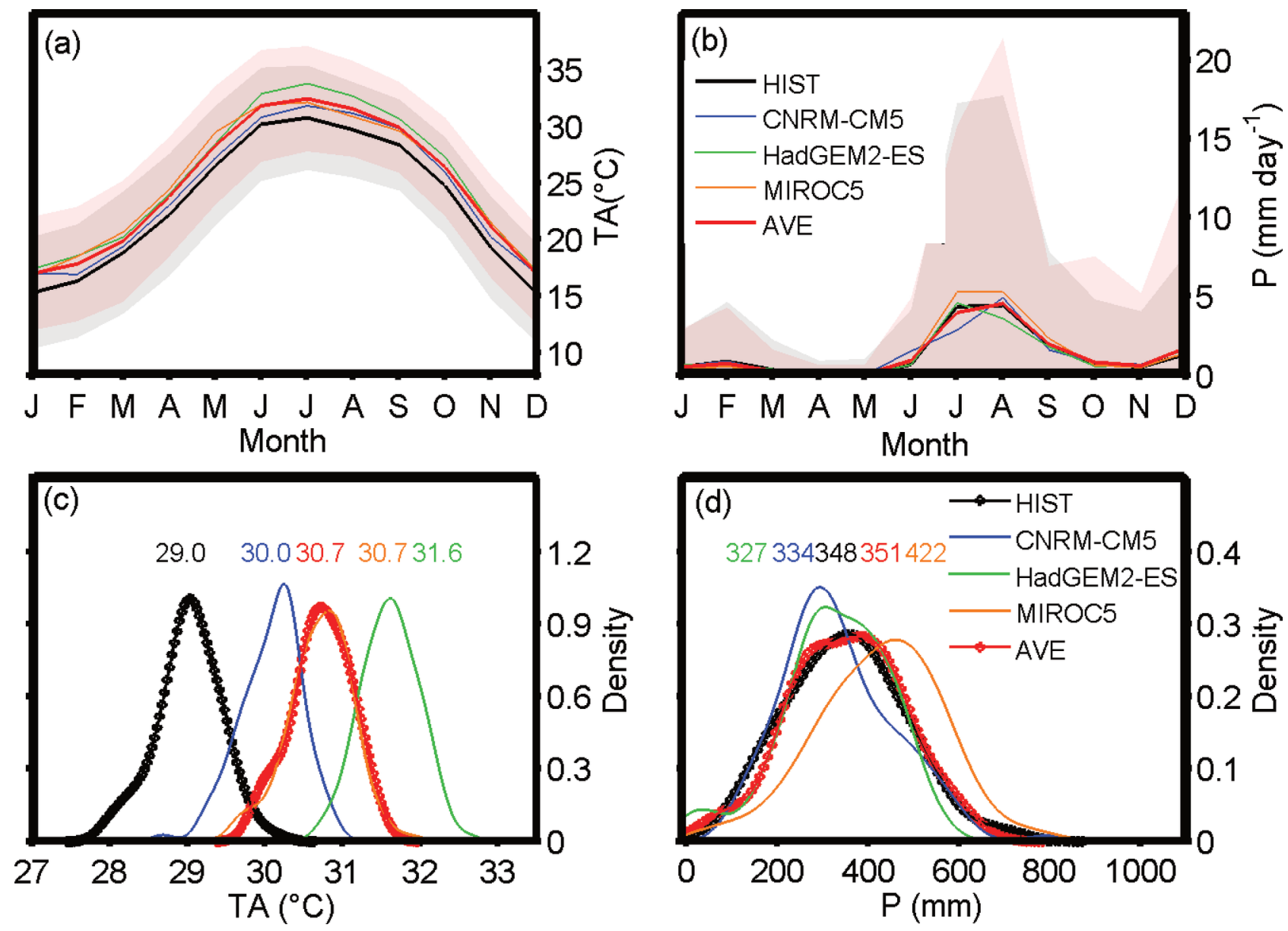

2017jg004361-f06-z-.eps 

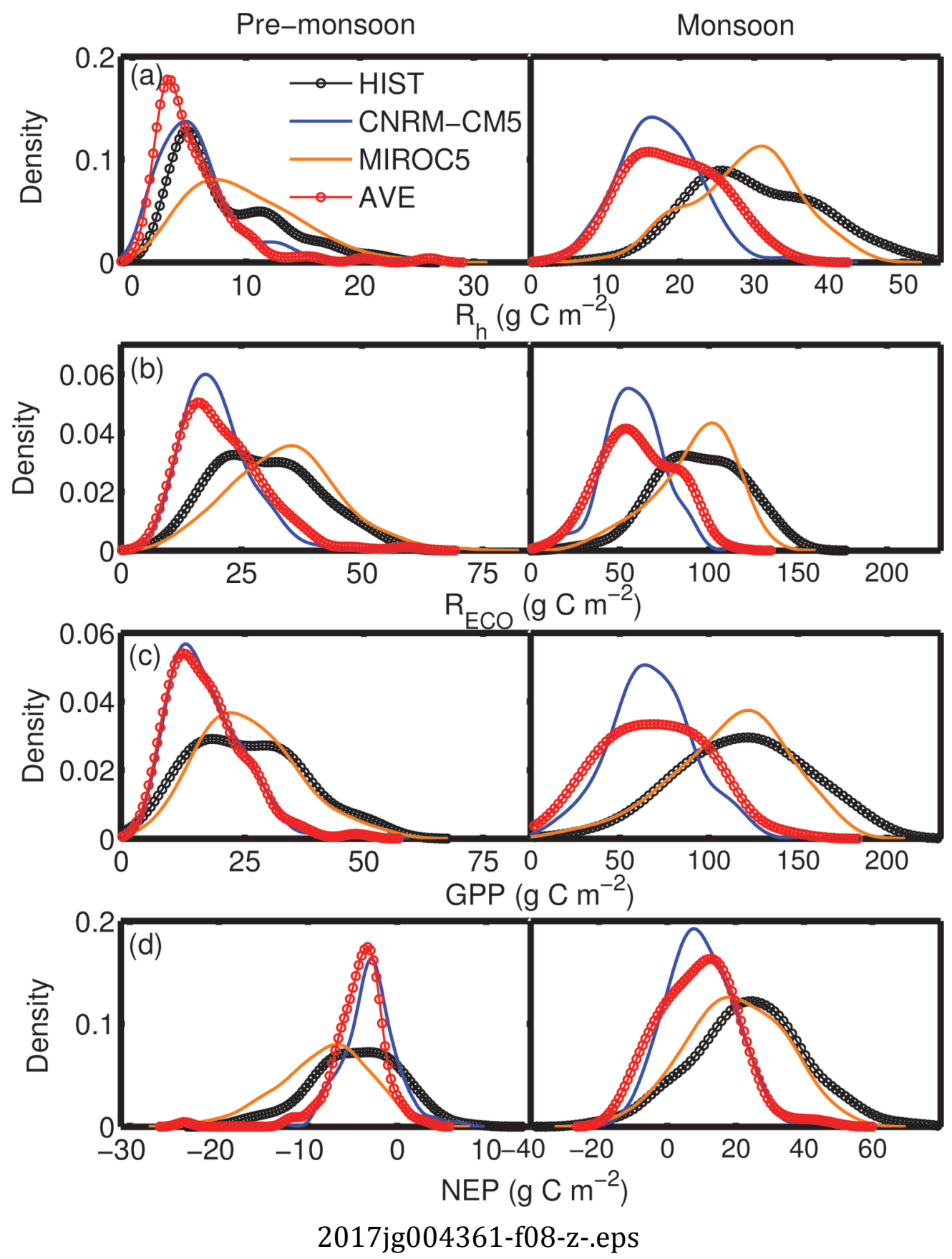

This article is protected by copyright. All rights reserved. 

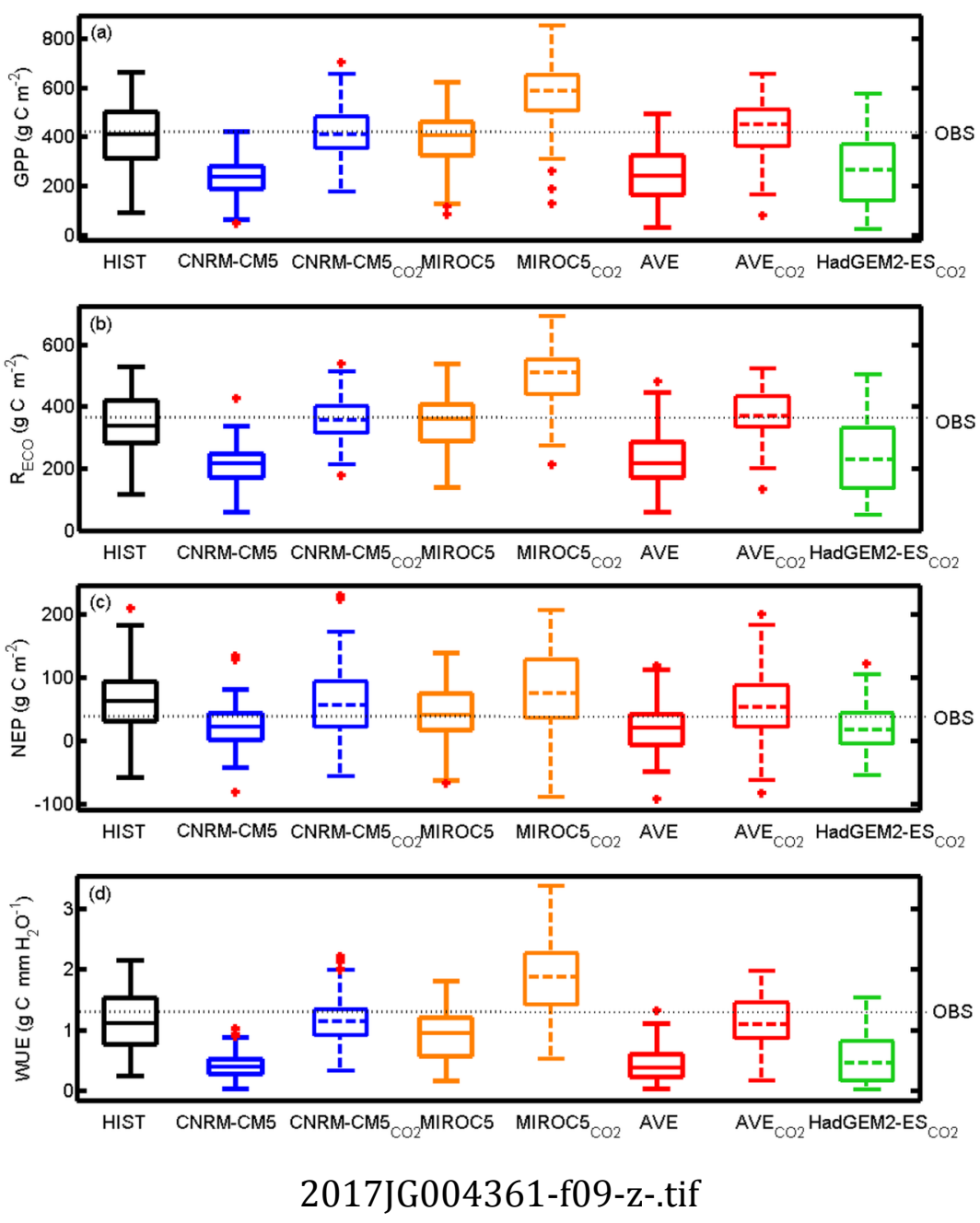

This article is protected by copyright. All rights reserved. 